\section{崊图 Digital Commons@}

Loyola Marymount University

LMU Loyola Law School
Loyola of Los Angeles Entertainment Law Review

Volume 30

Number 3 The Grammy Foundation

Entertainment Law Initiative 2010 Writing

Article 1

Competition

$6-22-2010$

\title{
Searching inside Google: Cases, Controversies and the Future of the World's Most Provocative Company
}

Jon M. Garon

Hamline University School of Law

Follow this and additional works at: https://digitalcommons.Imu.edu/elr

Part of the Law Commons

\section{Recommended Citation}

Jon M. Garon, Searching inside Google: Cases, Controversies and the Future of the World's Most Provocative Company, 30 Loy. L.A. Ent. L. Rev. 429 (2010).

Available at: https://digitalcommons.Imu.edu/elr/vol30/iss3/1

This Article is brought to you for free and open access by the Law Reviews at Digital Commons @ Loyola Marymount University and Loyola Law School. It has been accepted for inclusion in Loyola of Los Angeles Entertainment Law Review by an authorized administrator of Digital Commons@Loyola Marymount University and Loyola Law School. For more information, please contact digitalcommons@lmu.edu. 


\title{
SEARCHING INSIDE GOOGLE: CASES, CONTROVERSIES AND THE FUTURE OF THE WORLD'S MOST PROVOCATIVE COMPANY
}

\author{
By Professor Jon M. Garon*
}

For a company whose motto is "Don't be evil," Google certainly has its share of detractors. The company is at the center of numerous controversies that will determine how people use the Internet, find information, and communicate with each other. The past year has involved both business launches and legal decisions that will reshape Google's future, alter the online environment, and potentially revise copyright and trademark law, including: the marketing of trademarks in online search, the proposed Book Search settlement, the Viacom $v$. YouTube copyright infringement case, and looming antitrust investigations. The article explores the future of Google as it consolidates its control over online search and advertising and expands into telecommunications, mobile devices and cloud computing.

\section{INTRODUCTION}

Google has grown to become the largest U.S. advertising company and a supplier of a wide array of software products. ${ }^{1}$ As this corporate behemoth reaches its teen years, the time has come to see how it is growing to meet its corporate goals and how the advertising giant affects the world it bestrides.

\footnotetext{
* Professor of Law, Hamline University School of Law; J.D. Columbia University School of Law 1988. Prior versions of the article were prepared for the 2009 Midwest IP Institute and the 2010 Committee of Cyberspace Law of the ABA Business Law Section, Winter Working Meeting. I would like to thank Susan Stephan for her insights and comments on this project and Stacy Blumberg Garon for her help and support.

1. Natalie Zmuda, E-tailers Seek Revenue Boost From Ads That May Even Tout Rivals, ADVERTISING AGE, Mar. 8, 2010, available at $\mathrm{http}: / /$ adage.com/digital/article?article_id=142652 ("Google is the largest seller of text ads through its AdSense program (that also includes display ads), which collectively generated $\$ 5.2$ billion in revenue for publishers in 2009."); Mike Swift, Google's Stated List of Competitors Grows From Two to 10, SAlt LAKE TRIB., Mar. 13, 2010 ("Americans use Google for about two-thirds of U.S. searches, and the company has more than 70 percent of U.S. search advertising revenue, and about 90 percent in Europe - say the expanded list of competitors is an attempt by Google to paper over its dominance.").
} 
"Don't be evil.". As Google explains to its employees, the phrase is "about providing our users unbiased access to information, focusing on their needs and giving them the best products ... [b]ut it's also about doing the right thing more generally-following the law, acting honorably and treating each other with respect." 3 The company tells its employees to pay attention to these issues. ${ }^{4}$ At the same time, however, regulators and critics around the globe are beginning to question the ability of Google to stay true to this mission. ${ }^{5}$ This review hopes to take the admonition seriously: “[D]on't be evil, and if you see something that you think isn't right—speak up!"

\section{THE GOOGLE CORE}

Google is an advertising company that primarily uses its patented page ranking technology, named PageRank, to sell advertising. ${ }^{7}$ The PageRank technology was created by company founders Larry Page and Sergey Brin while at Stanford University. ${ }^{8}$ Stanford holds the PageRank patent, which expires in 2017. ${ }^{9}$ Google holds an exclusive license for the PageRank patent by an agreement which has been extended through 2011. ${ }^{10}$ Under the terms of that license, the Google license will become non-exclusive after 2011 unless the terms of the agreement are modified. ${ }^{11}$ Google has continued to develop its PageRank technology, which may provide it substantially greater benefits from the patent than competitors will have once the patent is available on a non-exclusive basis.

2. Google.com, Google Investor Relations: Google Code of Conduct, http://investor.google.com/conduct.html (last visited Aug. 10, 2009).

3. $I d$.

4. Id.

5. See generally Fed. TRAde COMM'N, FTC FiLE No. 071-0170, In the MATTER OF Google/DoubleClick: Dissenting STATEMEnt of Commissioner PAMEla Jones HaRbour (2007), available at http://www.ftc.gov/os/caselist/0710170/071220harbour.pdf [hearinafter Google/DoubleClick] (last visited Aug. 12, 2009). See Pamela Samuelson, The Dead Souls of the Google Book Search Settlement, 7 COMM. OF THE ACM, Jul. 1, 2009

6. Google Investor Relations, supra note 2, at 3.

7. See ZMUdA, supra note 1. See generally John Gruber, Google Is an Advertising Company, DARING FIREBALL, Aug. 29, 2005, http://daringfireball.net/2005/08/google_ad_company (stating that Google is not a platform based company, but judging from their profits an advertising company).

8. Google Inc., Annual Report (Form 10-K), at 16 (Dec. 31, 2009).

9. Id.

10. Id.

11. Id. 
In addition to its PageRank technology, ${ }^{12}$ Google uses text-matching techniques. ${ }^{13}$ Like Boolean searching, the text matching software looks to the number of times terms are utilized, the proximity of the text on the web page and other parameters to determine the rankings of the web search. ${ }^{14}$ The current update, codenamed Caffeine, began testing in $2009 .{ }^{15}$

Google has expanded its services significantly beyond the mere sale of advertising related to its search. ${ }^{16}$ In 2006 it acquired YouTube, the primary free host to user-generated video content. ${ }^{17}$ In 2007, it acquired DoubleClick, a complementary advertising company which placed ads on websites based on the content of those sites. ${ }^{18}$ Google released Orkut in 2004, a social network site $;{ }^{19}$ Picasa in 2006, a photo sharing service $;{ }^{20}$ and briefly operated the virtual world Lively in $2008 .{ }^{21}$

Google has also become a prime developer of new productivity tools for the Internet, ${ }^{22}$ often in direct competition with Microsoft, Yahoo!, and Apple as well as other Internet innovators such as Second Life, Skype, AOL and many smaller competitors. In 2008, Google launched Chrome as a browser designed to compete with Microsoft Internet Explorer, Apple Sa-

12. Google.com, Corporate Information: Technology Overview,

http://www.google.com/corporate/tech.html (last visited Mar. 5, 2010).

13. Id.

14. See The Spider's Apprentice, How to Use Web Search Engines, http://www.monash.com/spidap4.html (last visited Mar. 23, 2010).

15. Google Webmaster Central Blog, Help Test Some Next-Generation Infrastructure, Aug. 10, 2009, http://googlewebmastercentral.blogspot.com/2009/08/help-test-some-nextgeneration.html.

16. See generally Andrew Johnson, Game Time, ARIZONA REPUBLIC, July 9, 2009, at D1. See generally Nick Clark, Google vs Apple: The Gadget Showdown, INDEPENDENT, Jan. 5, 2010, available at $\mathrm{http}: / / \mathrm{www}$.independent.co.uk/life-style/gadgets-and-tech/features/google-vs-applethe-gadget-showdown-1857964.htm.

17. Pete Barlas, Google Says Video Ads on a Roll, InVESTOR's Business Daily, July 20, 2009, at A6.

18. Jim Puzzanghera \& Jessica Guynn, Google Gets Grip on Ad Firm, L.A. TIMES, Mar. 12,2008 , at $\mathrm{C} 1$.

19. Google.com, Google Milestones, http:/www.google.com/corporate/history.html (last visited Mar. 5, 2010).

20. Id.

21. Lively, http://lively.com/goodbye.html (last visited Feb. 27, 2010) ("Lively was a network of avatars and virtual rooms created and decorated by its users. Google launched Lively on July 8,2008 . . . Lively's users created thousands of cafes, bars, discos, tropical islands, treehouses, space stations, galleries, bedrooms and more... . The experiment ended December 31, 2008.").

22. See Google.com, Google Code: Google Apps, http://code.google.com/googleapps (last visited Mar. 23, 2010); see Google Inc., Google Press Center: Product Descriptions, http://www.google.com/press/descriptions.html (last visited Mar. 21, 2010). 
fari, Firefox, and others. ${ }^{23}$ Google is extending the Chrome brand into a netbook operating system, which it expects to launch in 2010, directly competing with the core products of both Microsoft and Apple. ${ }^{24}$

In addition, Google has created Android, a separate operating system for smart phones and other Internet enabled devices. ${ }^{25}$ The Android operating system is supported by the "Open Handset Alliance," a Googlesupported manufacturing consortium. ${ }^{26}$ Android competes directly with RIM BlackBerry, Microsoft's Windows CE/Mobile, Apple's iPhone, Palm's Pre, and the Symbian Ltd. OS (which is a market leader outside the United States). ${ }^{27}$ Google had further attempted to extend its position in cellular phones with the launch of its own handset named Nexus One, ${ }^{28}$ which was a direct competitor to Apple and Google's partners in the Open Phone Alliance, however Google has since terminated the project. ${ }^{29}$ Ultimately, Google was attempting to uncouple consumers' purchase of handsets from their choice of cellular phone carriers. ${ }^{30}$ Google's other web applications include Google Docs, Gmail, Blogger, Sites, SketchUp, Talk, Google Voice, and Google Book Search. ${ }^{31}$ Google supports a nonprofit foundation and has recently launched a venture capital fund. ${ }^{32}$

Despite all Google's activities, ninety-seven percent of its revenue is reported to come from advertising. ${ }^{33}$ Looking at the wide array of products

23. Google also had a distribution agreement with Firefox to promote that browser. See Stephen Shankland, Google Chrome: Browser Competition Back in High Gear, CNET NEWS, Sept. 2, 2008, http://news.cnet.com/google-chrome-browswer-competition-back-in-high-gear/.

24. Johnson, supra note 16, at D1.

25. See Michelle Quinn, Helping Digit-ize Google Phones, L.A. TIMES, Oct. 1, 2008, at C1; see also Clark, supra note 16. at 40

26. Id.; Brian Garrity, Google Not Hung Up By Phone Makers, N.Y. Post, Sept. 24, 2008,

27. See Quinn, supra note 25; Clark, supra note 16; Mark Long, Android's Rise Crimps Palm's Sales and Revenue, NEWSFACTOR NETWORK, Feb. 25, 2010, http://www.newsfactor.com/news/Android-s-Rise-Hurts-Palm-sSales/story.xhtml?story_id=0220001UFKRG\&full_skip $=1$.

28. Clark, supra note 16.

29. Bob Pegoraro, Google Nixes Nexus One, WASH. Post, July 19, 2010, available at $\mathrm{http}: / /$ voices.washingtonpost.com/fasterforward/2010/07/google_nixes_nexus_one.html.

30. Hiawatha Bray, Cellphone Aims to Reinvent Industry, Boston GloBe, Jan. 14, 2010 , at B7 (describing the strategy for Google is to ultimately separate the purchase of the cellular phone handset from the carrier, a strategy not actually working with the Nexus One thus far). 31. Google.com, Google Press Center: Product Descriptions, http://www.google.com/press/descriptions.html (last visited Mar. 21, 2010); More Google Products, http://www.google.gom/intl/en/options/ (last visited Mar. 21, 2010) [hereinafter Google Product Descriptions]

32. Google Milestones, supra note 19.

33. Barlas, supra note 17 , at A6. 
and services it provides, one can wonder whether Google still has a focus. Perhaps Google is treading the path of IBM, growing too diffuse, risking antitrust problems and thrashing in the market without a clear direction. IBM reinvented itself as a service company, but only after fighting a twenty-year antitrust investigation, the launch of competitors like Microsoft, and losing the PC market it had created. ${ }^{34}$ Or perhaps Google is following in Microsoft's footsteps, becoming the very company its founders most despised; shifting from innovator to aggregator of innovation, acquiring its market share rather than innovating its growth, and struggling to extend its powerful brand into fields in which it has neither presence nor expertise. $^{35}$ Or perhaps the mantra of "don't be evil" will help it chart a third course, which enables it to remain the darling of the public and the stockholders alike.

\section{MiXed Messages AND MERGERS}

Google has grown through both innovation and acquisition. ${ }^{36}$ The most controversial was in April 2007, when it purchased DoubleClick, the leading firm in display ad placement. ${ }^{37}$

Although Google rules the market for targeted text ads that are linked to search results on its own and others' websites, New York-based DoubleClick [was] a leading provider of technology to deliver elaborate, targeted display ads to websites. Mountain View, [California]-based Google aims to create a one-stop, fullservice shop for companies placing ads online and off. ${ }^{38}$

34. Fred Vogelstein, Why Is Obama's Top Antitrust Cop Gunning for Google?, WIRED MAGAZINE, July 20, 2009, available at http://www.wired.com/techbiz/it/magazine/1708/mf_googlopoly?currentPage=all.

35. Christine Varney, head of the Justice Department's Antitrust Division, provided her prediction of the future.

"For me, Microsoft is so last century. They are not the problem." The U.S. economy will "continually see a problem - potentially with Google" because it already "has acquired a monopoly in Internet online advertising," she said ... "When all our enterprises move to computing in the clouds and there is a single firm that is offering a comprehensive solution ... you are going to see the same repeat of Microsoft."

Eric Krangel, Obama's Antitrust Pick: Google is the New Microsoft, BUSINESS INSIDER, Feb. 18, 2009, http://www.businessinsider.com/obamas-antitrust-pick-google-is-the-newmicrosoft-2009-2.

36. See, e.g., Louise Story \& Miguel Helft, Google Buys an Online Ad Firm for \$3.1 Billion, N.Y. TIMES, Apr. 14, 2007, at B1; Reuters, Google to Supply Search Ads to EBay, L.A. TiMES, Aug. 29, 2006, at C2.

37. Story \& Helft, supra note 35 , at B1.

38. Puzzanghera \& Guynn, supra note 18 , at $\mathrm{C} 1$. 
A Federal Trade Commission antitrust review cleared the merger in December 2007. ${ }^{39}$ Although a four-to-one majority found no horizontal monopoly and no lessening of competition, the dissenting Commissioner took a more forward-looking view:

[E]ven more troubling is that the combination of Google and DoubleClick likely will affect the evolution of the entire online advertising market-especially in light of existing network effects, and the tremendous additional network effects the transaction will generate. ... By purchasing DoubleClick, Google will acquire data that will contribute to, and exacerbate, network effects. As a result, the Google/DoubleClick combination is likely to "tip" both the search and display markets in Google's favor, and make it more difficult for any other company to challenge the combined firm. ${ }^{40}$

The Google/DoubleClick merger was only one such acquisition that raised questions regarding the ability of competitors to overcome the network effects of Google's omnipresence. In the fall of 2008, Google and Yahoo! were forced to abandon a proposed agreement to have Google fulfill some of Yahoo's ad searches due to Justice Department objections. ${ }^{41}$

One year earlier, Google acquired YouTube for $\$ 1.65$ billion. $^{42}$ In the three years since the acquisition, YouTube continues to lose money and has started a transition from user-generated content to content provided by the traditional movie and television studios. ${ }^{43}$ Along the way, of course, it embroiled itself in a billion dollar lawsuit with some of those same content producers over the unauthorized posting of film and television content by YouTube users. ${ }^{44}$

39. GoOGle/DoubleClick, supra note 5.

When a publisher side ad server makes a call to retrieve an advertisement, the advertiser side ad server determines the optimal advertisements, pulls that ad from its inventory, and serves it into the designated place on the publisher's web page. Advertiser side ad servers also provide key data that is used to plan, manage, maintain, track, and analyze the results of online campaigns across multiple publisher websites. Like publishers, advertisers pay for the use of ad serving services on a cost per thousand ads served.

40. GOOGLE/DOUBLECLICK, supra note 5. ("A network effect arises when a good or service increases in value as more people use it. Feedback fosters acceptance and enhances popularity, which generates even more feedback, in a continually self-reinforcing loop.").

41. Press Release, U.S. Dep't of Justice, Yahoo! Inc. and Google Inc. Abandon Their Advertising Agreement (Nov. 5, 2008), available at http://www.justice.gov/opa/pr/2008/November/08-at-981.html.

42. Daniel Lyons, Watch the Funny Kittens!, NewSwEEK, July 20, 2009, at 28.

43. Id.

44. Anne Broache \& Greg Sandoval, Viacom Sues Google Over YouTube Clips, CNET.COM, Mar. 13, 2007, http://news.cnet.com/Viacom-sues-Google-over-YouTube- 
If the DoubleClick merger caused antitrust concerns, the YouTube acquisition raised the opposite question: why acquire a money-losing aggregator of Internet videos? Never fully explained by the company, the elusive answer may also be tied to Google's long-term media-dominance strategy. Broadcast television and radio are no different in business organization than the search business - in both cases, the broadcaster displays content free to the consumer but surrounded with advertising. From this perspective, YouTube is no different from CBS, Yahoo, or a web search.

The difference between YouTube and broadcast television remains profitability. ${ }^{45}$ Although Google does not break out YouTube income, analysts continue to acknowledge the losses at YouTube. ${ }^{46}$ While traditional media is shrinking, it continues to be profitable, and it is further extending its reach. ${ }^{47}$ Founded by Fox and NBC, Hulu.com has already earned greater revenue than YouTube on a fraction of its audience base. ${ }^{48}$ The potential to extend the per-viewer average revenue becomes significant. ${ }^{49}$ Google has recognized the shift by entering into distribution agreements with traditional media companies. ${ }^{50}$

Ironically, Hulu embodies the disruptive technology threatening the traditional broadcast television industry. Hulu is on-demand television which directly competes with traditional television. ${ }^{51}$ YouTube's usergenerated content reflects a different content segment. ${ }^{52}$ More accurately, however, YouTube still competes for viewership with traditional television, and while the tastes and format of YouTube may vary from that of broad-

clips/2100-1030_3-6166668.html.

45. See Daniel Lyons, Old Media Strikes Back, NewsweEK, Mar. 2, 2009, at 13.

46. Id. ("[Arash Amel, analyst for researcher Screen Digest] estimates that last year Hulu took in $\$ 65$ million in U.S. ad revenue and cleared $\$ 12$ million in gross profit, while YouTube generated $\$ 114$ million in U.S. revenue but had no gross profit. This year Amel estimates Hulu's revenue will grow to $\$ 175$ million in the U.S. and that YouTube will take in slightly less.”).

47. See, e.g., Hulu.com, Media Info, http://www.Hulu.com/about (last visited Mar. 5, 2010).

48. Lyons, Old Media Strikes Back, supra note 44, at 13; see also Barlas, supra note 17, at A6. ("YouTube had 99 million unique U.S. visitors in June, up 38\% from 71.7 million in June 2008, says market tracker Nielsen Online. Hulu, owned by Walt Disney and other media companies, ranked No. 2 with just 10.6 million visitors. Users watched more than 6.1 billion video streams on YouTube in June. Hulu was No. 2 with 348,310 million, says Nielsen.").

49. See Barlas, supra note 17 , at A6.

50. See, e.g., Press Release, GoDigital Media Group, GoDigital Media Group Adds Premium Film and Television Content to YouTube (Jan. 21, 2010), available at http://finance.yahoo.com/news/GoDigital-Media-Group-Adds-iw-1413154268.html?x=0\&.v=1.

51. See Hulu.com, Media Info, supra note 46.

52. See Don Reisinger, Can Hulu be a Bigger Business Than YouTube?, TECHCRUNCH.COM, Sept. 1, 2008, http://techcrunch.com/2008/09/01/can-hulu-be-a-biggerbusiness-than-youtube/. 
cast television, such differences will continue eroding as audiences gravitate to YouTube as a source of film and television content. ${ }^{53}$

So the question remains whether Google's acquisition of YouTube was a short-sighted folly or a long-term strategy for dominance. ${ }^{54}$ If the broadcasters continue to decline, a central site that delivers content to computers, portable music/video devices, cellular phones and Internet-equipped televisions could become the new media hub. Consumers want convenience and they prefer free. While iTunes and the iPhone are convenient, they are tethered to a proprietary platform with high equipment costs and noticeable content costs. ${ }^{55}$ Hulu is great for traditional television and movies. ${ }^{56}$ Google is the quintessential content aggregator-delivered for free in exchange for advertising. ${ }^{57}$ Therefore, YouTube may be a long-play for Google. But with such a dominant audience base, it will pose a formidable beachhead against other participants entering the business.

Google's history with traditional media may suggest that it has been motivated by a strategy to control ad placement across all media. ${ }^{58}$ Google attempted to enter the offline advertising business for newspapers, radio and television as an extension of its Internet dominance, but with far less success. ${ }^{59}$ For two years, Google tried to operate a business placing print ads ${ }^{60}$ and though the program grew to 800 newspapers, tending to control only the supplemental ad space that the papers were unable to sell. ${ }^{61}$ As a result, Google had to close the print ad business, and a month later, Google closed its radio ad program as well, ${ }^{62}$ eventually selling the division with its 3600 employees. ${ }^{63}$ Google continues to persevere in advertising sales for broadcast television, perhaps because of its long-term synergy with YouTube. $^{64}$

53. Id.

54. Infra Part X (for discussion on YouTube's copyright litigation).

55. Julia Layton \& Jonathan Strickland, How iTunes Works, HowSTUFFWorKS.COM, http://electronics.howstuffworks.com/itunes.htm/printable (last visited Mar. 5, 2010).

56. See Greg Sandoval, Hulu's Backers Bicker as Web Video Soars, CNET.COM, http://news.cnet.com/8301-31001_3-10398698-261.html (last visited Apr. 16, 2010).

M5.

$$
\text { 57. See Jack Romanos, The Fine Print in Google's Plan, L.A. TIMES, Jan. 15, 2006, at }
$$

58. See Miguel Helft, Google Ends Sale of Ads in Papers After 2 Years, N.Y. TIMES, Jan. 21, 2009, at B3 [hereinafter Google Paper Ads].

59. Id.

60. Id.

61. Id.

62. Miguel Helft, Google Ends Its Project for Selling Radio Ads, N.Y. TIMES, Feb. 13, 2009, at B3 [hereinafter Google Radio Ads].

63. Tribune News Service, Google Cuts Pair of Deals, CHI. TriB., Aug. 6, 2009, at C26.

64. Google Radio Ads, supra note 62. 
Taken together, the strategy of acquiring companies to expand beyond ad placement into the role of ad broker and broadcaster reflects a solid, vertical integration for the advertising giant. ${ }^{65}$ The FTC analysis of the DoubleClick merger highlights the strategy. ${ }^{66}$ Google chose to purchase technology companies that provide toeholds into advertising delivery in each media, allowing it to expand both horizontally and vertically. ${ }^{67}$ Rather than become DoubleClick's competitor, Google chose to pay billions of dollars to eliminate a future competitor from the field. ${ }^{68}$ Implicit in the strategy, Google further benefits by eliminating a potential acquisition target for its chief competitors - namely, Microsoft, Apple and Yahoo!.

This approach is not new to Google. To the contrary, it goes to the central business strategy of the company. ${ }^{69}$ As Mark Cuban recently noted, Google "almost joined a long list of companies in the 'great technology, no business model' archives." tion lawsuit from Overture Services, Inc., "asserting that certain services infringed Overture's U.S. Patent No. 6,269,361" (361 patent). ${ }^{71}$ Initially, Google "denied that it infringed the patent and alleged that the patent was invalid and unenforceable." " The patent in question covered the heart of the AdWords business model. ${ }^{73}$

In 2003, Yahoo! acquired control of Overture and in so doing, took ownership of the Google core business model. ${ }^{74}$ As Google prepared to go public, it entered into a comprehensive settlement agreement with Yahoo!, pricing the "fully-paid, perpetual license to the patent" and mutual release

65. See Bob Keefe, Critics Decry Expansion of Google, ATLANTA JOURNALConstitution, Aug. 25, 2007, at 4C.

66. See generally GoOGLE/DoubLECLICK, supra note 5.

67. See Google Radio Ads, supra note 62 (noting that the entrance into radio ad sales, for example, came with the purchase of dMarc Broadcasting).

68. See generally Keefe, supra note 65 . One can only surmise that the threat that Google would launch a competitive product may have both brought the owners of DoubleClick to the bargaining table and affected the sales price, notwithstanding the $\$ 3.1$ billion paid for the acquisition.

69. See, e.g., Google Radio Ads, supra note 62.

70. Mark Cuban, The Wisest \$28.5 Million Ever Spent, NewsweEK, Nov. 30, 2009, at 17.

71. Google Inc., Quarterly Report (Form 10-Q/A), at 13 (June 30, 2004) [hereinafter Google Quarterly Report].

72. $I d$.

73. See Usman Latif, Google's Bid-for-Placement Patent Settlement Cover-up, TECHUSER.NET, May 31, 2005, http://www.techuser.net/gcoverup.html (last visited Nov. 29, 2009).

74. See Stefanie Olsen \& Margaret Kane, Yahoo to Buy Overture for $\$ 1.63$ Billion, CNET.COM, July 14, 2003, http://news.cnet.com/2100-1030_3-1025394.html (last visited Nov. 29, 2009). 
of 2.7 million shares of Google Class A common stock. ${ }^{75}$ The 2.7 million shares of Google stock, one percent of its stock at the time, covered the Overture 361 patent and other disputes between the parties. ${ }^{76}$ From a competitive standpoint, the settlement was the flexion point between the two search companies. Google was free to grow its business model and to stop denying the patentability of the AdWords methodology. Yahoo!, which had paid $\$ 1.63$ billion to acquire Overture, received substantially less than one-fifth the value of Overture from the Google settlement. ${ }^{77}$ Yahoo! struggled to recapture its investments and began looking back on its strategy while Google cleared itself of potentially game-ending litigation and moved forward as the dominant search engine on the Internet.

\section{So Why THE SOFTWARE?-The NON-AdVERTISING STRATEGY}

An admittedly cynical interpretation of Google's “don't be evil" strategy flows from its own approach to advertising. Only recently did Google begin to advertise. According to the advertising giant's behavior, advertising is evidently for chumps. Nonetheless, Google has spent some ad money on billboards to promote its software suite and its apps, including Google Docs. ${ }^{78}$ A less cynical view of Google recognizes that since Google already associates its name with every ad sold on behalf of its various advertising businesses, it needs a different strategy to promote its brand.

By providing free products, Google reinforces its name as an Internet

75. Google Quarterly Report, supra note 71, at 13 (June 30, 2004).

76. See Latif, supra note 73.

77. See id.

At the time of the patent settlement disclosure, 2.7 million shares of Google represented roughly 1 percent of the company. Google estimated that the shares were worth somewhere between \$260 and \$290 million. This estimate was based on Google's proposed IPO price range of $\$ 108$ to $\$ 135$ a share, which was subsequently lowered to $\$ 85$ a share. Interestingly, even the $\$ 290$ million number does not represent any sort of adequate return on Yahoo's \$1.63 billion Overture investment. Yahoo was licensing critical patents to Google at a critical time for less than one fifth of what it paid to acquire them.

Interestingly, Google never paid anything even remotely close to $\$ 290$ million for the patents. Google quite successfully managed to muddle up the math by jumbling together the numbers of the patent licensing settlement with the settlement of a separate second dispute with Yahoo.

Latif, supra note 73. Mark Cuban's Newsweek column priced the acquisition at an extremely low calculation of $\$ 28.5$ million, but Cuban gives no explanation of how he arrived at that calculation. See Cuban, supra note 70, at 17.

78. Tom Krazit, Google Aims at Commuters with Google Apps Ads, CNET.COM, http://news.cnet.com/8301-1023_3-10301571-93.html (last visited Aug. 13, 2009). 
destination and resource. ${ }^{79}$ Some of these services deliver behavioral advertising while others do not generate direct revenue. As a business strategy, these free products are less expensive to develop and deliver than the comparable amount of direct advertising. Moreover, direct advertising is generally not friendly, so the Google app strategy makes sense from its corporate agenda.

The bonus for the strategy is the cost aspect of the developed products. By focusing on the core business of Microsoft (including free competitive products for operating systems, browsers, documents, spreadsheets, presentations, e-mail, and calendars), Google highlights Microsoft's vulnerability to alternatives. ${ }^{80}$ Microsoft's attempt to retaliate with Bing had limited impact since it does not compete with the AdSense advertising placement component of Google's ad network.

\section{INTERLOCKING DIRECTORSHIPS A MONOPOLY DANGER-WHO KNEW?}

One consequence of the free app marketing strategy for Google has been the strategy clash with Google's former chum, Apple. Eric Schmidt, Google's CEO, had joined the Apple board of directors in $2006 .{ }^{81}$ Shortly thereafter, Schmidt joined Apple CEO Steve Jobs "to announce Apple's first iPhone." 82 At the time, Schmidt "joked about merging the two companies and calling it 'AppleGoo,' citing the compatibility in corporate cultures." 83

The cultures were very compatible, both driven by innovation and a deep distrust, if not hatred, of common competitor, Microsoft. Apple and Microsoft were direct competitors in almost every product line, including computer operating software, applications, music players and smart phone systems. ${ }^{84}$ Google's web-based apps reduced Microsoft's advantage from

79. See Google Press Center: Product Descriptions, supra note 31 (showing a list of many of the free useful products Google offers).

80. See J. Nicholas Hoover, Google, IBM Take Another Run at Microsoft's Office Suite, INFORMATIONWEEK, Sept. 22, 2007, available at http:/www.informationweek.com/news/software/linux/showArticle.jhtml?articleID=202100053 (noting that despite the competitive products, Office retains roughly a ninety-five percent market share).

81. Alex Pham, Google CEO Schmidt Resigns from Apple Board, L.A. TIMES, Aug. 4, 2009 , at B4.

82. Id.

83. Id.

84. See David Sarno, Microsoft Bids for Relevancy in Smart Phones, L.A. TIMES, Feb. 16, 2010, at B3; see also Allan Hoffman, Web-Based Software Gaining on Once-Mighty Microsoft, STAR-LEDGER (NeWARK), Jan. 21, 2009, at 21; Ben Parr, Google Is Now Apple's Greatest Enemy: Here's Why, MASHABLE.COM, http://mashable.com/2010/01/20/apple-microsoft-v- 
its installed base, a change which favored Apple. ${ }^{85}$

In the years since the iPhone launch, however, the two companies have been on a collision course. ${ }^{86}$ Google's Android phone software competes as directly with the iPhone as with the Windows Mobile platform; Google's Chrome browser competes directly with Apple's attempt to move its Safari browser onto PCs, and the Chrome operating system announcement could put Apple's modest market share at far greater risk than Windows. $^{87}$ Both Apple and Google court the student and individual user, while Windows greatest strength remains in the corporate market. ${ }^{88}$ Even worse for Apple, Chrome is designed to support the netbook market segment, the lowest cost web-focused machines. ${ }^{89}$ These compete with Apple's iPhone as much as low-end computer sales. ${ }^{90}$ The growth of the netbook market has put significant price pressure on Apple's generally more expensive hardware. ${ }^{91}$

With such substantial overlap between Apple's and Google's expansion, it should have been obvious much earlier that the two companies had grown to become direct competitors. By May 2009, the FTC began an investigation concerning this overlap. ${ }^{2}$ In August 2009, Schmidt finally agreed to step down. ${ }^{93}$ Surprisingly, his resignation did not come before the competition turned uncomfortably anticompetitive:

On August 3, 2009, Apple announced that Eric E. Schmidt, Chief Executive Officer of Google, was stepping down from its

google (last visited Mar. 4, 2010).

85. See Johnson, supra note 16, at D1 ("Some technology experts say formidable searchengine operator Google Inc. dropped a bomb on software giant Microsoft Corp. by announcing Tuesday night that it is developing its own computer-operating system."). See also Mike Swift, Google, Microsoft Vie for 'cloud' Control, CHI. TRIB., Dec. 24, 2009, at 21.

86. See generally Pham, supra note 81.

87. See Johnson, supra note 16; see also Pham, supra note 81.

88. See generally Arik Hesseldahl, Students Will Help Save Apple, Business WeEK, Aug. 28, 2008, available at

http://www.businessweek.com/technology/content/aug2008/tc20080827_522941.htm; Hoover, supra note 80 .

89. See Johnson, supra note 16.

90. See M.G. Siegler, Apple: Want a Netbook? Try An iPhone or iPod Touch (For Now), TECHCRUNCH, Apr. 22, 2009, http://techcrunch.com/2009/04/22/apple-want-a-netbook-try-aniphone-or-ipod-touch-for-now/.

91. See Pham, supra note 81.

92. Miguel Helft \& Brad Stone, Board Ties at Apple and Google Scrutinized, N.Y. TIMES, May 5, 2009, at B1.

93. Press Release, Federal Trade Commission, Statement of Bureau of Competition Director Richard Feinstein Regarding the Announcement that Google CEO Eric Schmidt Has Resigned from Apple's Board (Aug. 8, 2009), available at http://www.ftc.gov/opa/2009/08/googlestmt.shtm. 
board. "We have been investigating the Google/Apple interlocking directorates issue for some time and commend them for recognizing that sharing directors raises competitive issues, as Google and Apple increasingly compete with each other," said Bureau of Competition Director Richard Feinstein. "We will continue to investigate remaining interlocking directorates between the companies." 94

However, the investigation did not end there because Arthur Levinson, former CEO for Genentech Inc., remains on both the Apple and Google boards. ${ }^{95}$ In addition, former Vice President Al Gore serves as an Apple board member and as a senior advisor to Google, ${ }^{96}$ as does Bill Campbell. $^{97}$

Finally, in October 2009, Levinson recognized he had become a liability. ${ }^{98}$ Without much additional comment, Levinson resigned from the board of Google, but remains with Apple. ${ }^{99}$ The FTC issued a statement the day after Levinson resigned, commending the parties for resolving the conflict of interest without resorting to litigation:

"Google, Apple, and Mr. Levinson should be commended for recognizing that overlapping board members between competing companies raise serious antitrust issues and for their willingness to resolve our concerns without the need for litigation," said FTC Chairman Jon Leibowitz. "Beyond this matter, we will continue to monitor companies that share board members and take enforcement actions where appropriate."

The interest of the FTC and its jurisdiction under Section 8 of the Clayton Act evidently did not extend to Gore and Campbell, the two prominent Google advisors who remain on Apple's Board of Directors. ${ }^{101}$

Regardless of the actual inside information passed between the companies, the board of directors should have access to key strategies and trade

94. Id.

95. Pham, supra note 81 , at B4.

96. Id.

97. Cecilia Kang, Apple Director Resigns from Google Board, L.A. TIMES, Oct. 13, 2009, at B6.

98. See generally id.

99. Id.

100. Press Release, Federal Trade Commission, Statement of FTC Chairman Jon Leibowitz Regarding the Announcement that Arthur D. Levinson Has Resigned from Google's Board (Oct. 12, 2009), available at http://www.ftc.gov/opa/2009/10/google.shtm.

101. Id. (noting that Section 8 of the Clayton Act prohibits someone from serving as director of two competing corporations). 
secrets of its company. Mere advisors, of course, do not necessarily have the same access to inside information as do board members.

If the directors are shielded from the strategic inside information to avoid potential or actual conflicts of interest, then they may be failing to meet their fiduciary duties. Therefore, at a bare minimum the interlocking boards create the appearance of impropriety. Section 8 of the Clayton Act provides direct regulation of interlocking directorates, ${ }^{102}$ but the applicability of Section 8 depends on the level of financial competition. ${ }^{103}$

Section 8 prohibits, with certain exceptions, one person from serving as a director or officer of two competing corporations if two thresholds are met. Competitor corporations are covered by Section 8 if each one has capital, surplus, and undivided profits aggregating more than $\$ 10,000,000$, with the exception that no corporation is covered if the competitive sales of either corporation are less than $\$ 1,000,000$. Section 8(a)(5) requires the Federal Trade Commission to revise those thresholds annually, based on the change in gross national product. The new thresholds, which take effect immediately, are $\$ 25,319,000$ for Section $8(\mathrm{a})(1)$, and $\$ 2,531,900$ for Section $8(\mathrm{a})(2)(\mathrm{A}) .^{104}$

The interlock problem is self-evident. "[W]hen an individual simultaneously serves as an officer or director of two competing companies, he or she stumbles into a prime opportunity for collusion-for example, coordination of pricing, marketing, or production plans of the two companies." 105 The self-evident concept may be more difficult for the FTC to enforce. Given that Google has no "competitive sales" of its free products, the FTC will need to value the competitive products in a different manner if it wishes to use Section 8 jurisdiction.

Nonetheless, the interlocking board problem violates Google's internal policies on conflict of interest:

All of us should avoid circumstances that present even the ap-

102. Clayton Act of $1914 \S 8,15$ U.S.C. $\S 19$ (2009) ("No person shall, at the same time, serve as a director or officer in any two corporations . . . that are . . by virtue of their business and location of operation, competitors, so that the elimination of competition by agreement between them would constitute a violation of any of the antitrust laws ....").

103. See id.

104. Federal Trade Commission, Billing Code 6750-01P, REVISED JuRISDictional THRESHOLDS FOR SECTION 8 OF THE CLAYTON ACT, available at http://www.ftc.gov/os/2008/01/P859910sec8.pdf.

105. Gale T. Miller, Interlocking Directorates and the Antitrust Laws, 26 COLO. LAW. 53, 53 (1997); see also Benjamin M. Gerber, Enabling Interlock Benefits While Preventing Anticompetitive Harm: Toward an Optimal Definition of Competitors Under Section 8 of the Clayton Act, 24 YALE J. ON REG. 107, 112 (2007). 
pearance of such a conflict. When faced with a potential conflict of interest, ask yourself:

Would this relationship or situation embarrass me or Google if it showed up on the front page of a newspaper or the top of a blog?

Am I reluctant to disclose the relationship or situation to my manager, Legal or Ethics \& Compliance?

Could the potential relationship or situation create an incentive for me, or be perceived by others to create an incentive for me, to benefit myself, my friends or family or an associated business, at the expense of Google?

If the answer to any of these questions is 'yes,' the relationship or situation is likely to create a conflict of interest, and you should avoid it. ${ }^{106}$

Arguably, any conduct sufficient to trigger an FTC investigation should be considered "perceived by others to create an incentive . . . to benefit . . . an associated business, at the expense of Google." 107 A second reason the interlocking directorates violate Google's internal policy stems from its potential to be a violation of the Sherman Act which prohibits combinations in restraint of trade. ${ }^{108}$

The expansion of Google from a search company to a software developer and media distributor changed its relationships with other companies in the field as well. From its inception as a search engine, Google predatorily faced off against Microsoft, which was slow to embrace the Internet, in its attempt to dominate the browsers needed to access the Internet. ${ }^{109}$

106. Google Investor Relations, supra, note 2 at $\S 3$.

107. $I d$.

108. 15 U.S.C. $\S 1$ (2006) ("Every contract, combination in the form of trust or otherwise, or conspiracy, in restraint of trade or commerce among the several States, or with foreign nations, is declared to be illegal."); 15 U.S.C. § 2 (2006) ("Every person who shall monopolize, or attempt to monopolize, or combine or conspire with any other person or persons, to monopolize any part of the trade or commerce ... shall be deemed guilty of a felony ...."); see also James F. Ponsoldt \& Christopher D. David, A Comparison Between U.S. and E.U. Antitrust Treatment of Tying Claims Against Microsoft: When Should the Bundling of Computer Software Be Permitted?, 27 NW. J. INT'L L. \& BUS. 421, 426 (2007).

109. Microsoft licensed third party software to launch its MSN search service in 1998, the 
When Google was a scrappy young company fighting the Microsoft colossus, its sniping tactics designed to tweak Microsoft had little market effect. Today, Google dominates the search market. ${ }^{110}$ Any actual collusion between Apple and Google regarding operating systems or browsers would violate the Sherman Act and sitting together in board meetings regarding these products cannot help but raise at least the appearance of impropriety. ${ }^{111}$ Schmidt's resignation is a good step, but all overlapping directors should be eliminated if the company takes its ethical code seriously.

\section{Antitrust CONCERns EXTEND to CONTENT - THE GOOGLE BOOK SEARCH SETTLEMENT}

Stemming from Google's drive to organize all information, ${ }^{112}$ it began the process of digitizing books at the nation's great libraries, starting with Page's alma mater, the University of Michigan. ${ }^{113}$

"Even before we started Google, we dreamed of making the incredible breadth of information that librarians so lovingly organize searchable online," said Larry Page, Google co-founder and president of Products. "Today we're pleased to announce this program to digitize the collections of these amazing libraries so that every Google user can search them instantly.

Our work with libraries further enhances the existing Google Print program, which enables users to find matches within the full text of books, while publishers and authors monetize that information," Page added. . . .

For publishers and authors, this expansion of the Google Print program will increase the visibility of in and out of print books,

same year that Google was launched and its founders started looking for buyers. In 2005, Microsoft replaced Yahoo! Search technology with its own software, significantly revising the product with Microsoft Live Search in 2006 and Bing in 2009. Reflecting the changing fortunes of these companies, Microsoft entered into a revenue agreement shortly after the launch of Bing under which Yahoo! has replaced all its search software with the Microsoft product in exchange for a revenue sharing agreement. See History of Search Engines: From 1945 to Google 2007, http://www.searchenginehistory.com/ (last visited Aug, 12, 2009).

110. See Vogelstein, supra note 33.

111. 15 U.S.C. $\S 1$ (2006).

112. See Google Milestones, supra note 19 ("Google's mission [is] to organize the world's information and make it universally accessible and useful.”).

113. Tom Tigani, University-Google Digitization Effort Turns Page Toward Future in Book Access, THE UNIVERSITY RECORD ONLINE, Dec. 4, 2006, available at http://www.ur.umich.edu/0607/Dec04_06/09.shtml. 
and generate book sales via "Buy this Book" links and advertising. For users, Google's library program will make it possible to search across library collections including out of print books and titles that weren't previously available anywhere but on a library shelf. ${ }^{114}$

The project has developed an unprecedented scale. Professor Pamela Samuelson described it as "[o]ne of the most significant developments in the history of books, as well perhaps in the history of copyright. . . ."115 The process resulted in an abortive competitive effort from Microsoft, and lawsuits by the Authors Guild and a group of commercial publishers. ${ }^{116}$ After three years of negotiations, the litigation resulted in a proposed settlement between the Authors Guild, the Association of American Publishers, and Google. ${ }^{117}$ The proposed settlement received preliminary approval November 14, 2008, but final approval has been delayed by public criticism and the Justice Department's interest in the settlement terms. ${ }^{118}$ After the parties made revisions to address these concerns, the District Court granted preliminary approval to the Amended Settlement Agreement on November 19, 2009.

114. Google Checks Out Library Books, http://www.google.com/press/pressrel/print_library.html (last visited August 17, 2009).

115. Pamela Samuelson, Google Book Search and the Future of Books in Cyberspace, MINN. L.REV. (forthcoming 2010) (manuscript at 1), available at

http://ssrn.com/abstract=1535067 [hereinafter Samuelson-Manuscript]

116. See Class Action Complaint at 2, The Authors Guild v. Google Inc., No. 05 CV 8136 (S.D.N.Y. 2005), available at

http://www.authorsguild.org/advocacy/articles/settlementresources.attachment/authors-guild-vgoogle/Authors\%20Guild\%20v\%20Google\%2009202005.pdf; see Complaint at 1, McGraw-Hill Co., Inc. v. Google Inc., No. 05 CV 8881 (S.D.N.Y. 2005), available at

http://www.authorsguild.org/advocacy/articles/settlementresources.attachment/mcgraw-

hill/McGraw-Hill\%20v.\%20Google\%2010192005.pdf.

117. See Amended Settlement Agreement, The Authors Guild v. Google Inc., No. 05 CV 8136 (S.D.N.Y. 2005), available at http://www.googlebooksettlement.com/ (last visited Jan. 20 , 2010). See also Google Books Settlement Agreement,

http://books.google.com/googlebooks/agreement/ (last visited Jan. 20, 2010); The Authors Guild v. Google Settlement Resources Page, http://www.authorsguild.org/advocacy/articles/settlementresources.html (last visited Jan. 20, 2010).

118. Order Granting Preliminary Approval of Amended Settlement, The Authors Guild v. Google Inc., No. 05 CV 8136 (S.D.N.Y. 2005), available at http://www.authorsguild.org/advocacy/articles/settlement-resources.attachment/111408-signedprelim/111408\%20Signed\%20Prelim\%20Approv.pdf; see also Statement of Interest by the U.S. Dept. of Justice Regarding the Proposed Settlement, Authors Guild, Inc. v. Google, Inc., Case No. 05 CV 8136 (S.D.N.Y. Sept. 18, 2009), available at http://www.usdoj.gov/atr/cases/f250100/250180.pdf

119. Order Granting Preliminary Approval of Amended Settlement Agreement, The 
The focus of the public concern has not centered on any copyright considerations. Google's action of copying materials which are not in the public domain violates the exclusive rights of authors and publishers, ${ }^{120}$ but such violations may be permitted under the law if it constitutes fair use. ${ }^{121}$ Interestingly, whether the public perceives Google's actions as copyright infringement or as fair use seems to turn on the individual's more general view of Google as a socially desirable public benefactor or as a piratical advertising shill. Even though "motive" is not part of the fair use analysis, such characterization often affects the fact finder's ultimate disposition. ${ }^{122}$ Reproduction of a work, unlike performance or display, does not need to be conducted publicly to constitute infringement. ${ }^{123}$ As courts have recognized, copying may still be actionable. ${ }^{124}$

[I]ntermediate copying . . . may infringe the exclusive rights granted to the copyright owner in section 106 of the Copyright Act regardless of whether the end product of the copying also infringes those rights. If intermediate copying is permissible under the Act, authority for such copying must be found in one of the statutory provisions to which the rights granted in section 106 are subject. $^{12}$

Of course, the copying of public domain materials is of high social utility and benefit. Those materials are not in question. Google has made these public domain works generally available, though it incorporates a Google watermark onto the PDF copy. ${ }^{126}$ Nonetheless, Google has already begun to make commercial use of its public domain library by licensing the collection to Sony for its e-book reader. ${ }^{127}$ This may have significant commercial utility for both Google and Sony, but because exploitation of the public domain for commercial advantage is economically efficient, it

\footnotetext{
Authors Guild v. Google Inc., No. 05 CV 8136 (S.D.N.Y. 2005), supra note 116.

120. See 17 U.S.C. $\S 106(2000)$.

121. Id. at $\S 107$.

122. Compare Campbell v. Acuff-Rose Music, Inc., 510 U.S. 569, 579 (1994) with

Harper \& Row, Publishers, Inc. v. Nation Enters., 471 U.S. 539, 549-50 (1985); Video Pipeline, Inc. v. Buena Vista Home Entm't, Inc., 342 F.3d 191, 198 (3d. Cir. 2003).

123. 17 U.S.C. $\S 106(2000)$. Public performance and display are distinguished from the other exclusive rights under the statute.

124. Video Pipeline, Inc., 342 F.3d at 207; Sega Enters. v. Accolade, Inc., 977 F.2d 1510, 1517-19 (9th Cir. 1992).

125. Sega, 977 F.2d at 1519.

126. See Samuelson-Manuscript, supra note 115 , at 1, n.7.

127. See Brief for Sony Electronics Inc. as Amici Curiae Supporting Proposed Google Book Search Settlement, Authors Guild, Inc. v. Google Inc., No. 1:05 CV 8136 (S.D.N.Y. Sept. 8, 2009), available at $\mathrm{http} / /$ thepublicindex.org/docs/letters/sony.pdf.
} 
should be lauded. ${ }^{128}$ Nonetheless, Professor Samuelson raises concerns that nothing in the proposed book settlement requires Google to "withdraw these books from display . . . or to charge for them in the future." 29 The only limit on Google regarding the public domain works is the public domain nature of the files. The mere scanning of the PDF is insufficient to make the books copyrightable. ${ }^{130}$ Moreover, it is unlikely the imposition of the watermark will rise to the level of trademark protection for the public domain works. ${ }^{131}$ "The right to copy, and to copy without attribution, once a copyright has expired, like 'the right to make [an article whose patent has expired] - including the right to make it in precisely the shape it carried when patented-passes to the public.""132 Were Google to attempt to extend any ownership on its public domain materials, it would not only violate a long line of established Supreme Court intellectual property precedent, but it would undoubtedly jump from public darling to imperial predator in a single step. ${ }^{133}$ Therefore, the public domain should remain safe since the public benefitted from its diligence.

Unlike the public domain materials, the copying by Google of copyrighted books, without authorization, constitutes intermediate copying without regard to the eventual display of those books. At first blush, the copyright case closest to the Google Book Project is UMG Recordings v. MP3.com, Inc., where, MP3.com provided a service similar to the service Google provides. ${ }^{134}$

[D] efendant MP3.com, on or around January 12, 2000, launched its "My.MP3.com" service, which it advertised as permitting subscribers to store, customize and listen to the recordings contained on their CDs from any place where they have an internet connection. To make good on this offer, defendant purchased tens of thousands of popular CDs in which plaintiffs held the copyrights, and, without authorization, copied their recordings onto its computer servers so as to be able to replay the recordings for its subscribers. ${ }^{135}$

128. $I d$.

129. See Samuelson-Manuscript, supra note 115 , at $1, \mathrm{n} .7$.

130. Feist Publ'ns v. Rural Tel. Serv. Co., 499 U.S. 340, 346 (1991) (“originality requires independent creation plus a modicum of creativity”); Matthew Bender \& Co. v. West Publ'g Co., 158 F.3d 693, 702 (2d Cir. 1998).

131. See Dastar Corp. v. Twentieth Century Fox Film Corp., 539 U.S. 23, 31-32 (2003).

132. Id. at 33 (quoting Sears, Roebuck \& Co. v. Stiffel Co., 376 U.S. 225, 230 (1964)).

133. See generally Sega, 977 F.2d at 1510.

134. UMG Recordings v. MP3.com, Inc., 92 F. Supp. 2d 349 (S.D.N.Y. 2000).

135. Id. at 350 . 
So MP3.com acted somewhat better than Google in that it purchased the works it copied. Nonetheless, even though the space-shifting is presumably fair use, the massive unauthorized intermediate copying is still actionable. ${ }^{136}$ The court did not even consider the issue closely. "The complex marvels of cyberspatial communication may create difficult legal issues; but not in this case. Defendant's infringement of plaintiff's copyrights is clear." 137 One feature of the Google Book Project, however, was not part of the MP3.com model. Copyright owners could "opt out" of the system. ${ }^{138}$

A brief application of the four statutory fair use prongs highlights the importance of Google's opt out policy. ${ }^{139}$ The benefits of creating an archive of the world's published knowledge is self-evident, so the digitizing would likely be deemed as an important and productive use of the works copied. Moreover, even though there is no transformation for any particular work, the archive as a whole could be deemed transformative, thus favoring Google. ${ }^{140}$ "The more substantial the contribution that the later author makes to the expressive domain by his use of copyrighted materials, the more likely that use is to be deemed a fair use. Courts call this type of use productive (or transformative) as distinct from simply reproductive (or

136. $I d$.

137. Id.

138. See Robin Jeweler, The Google Book Search Project: Is OnLine IndeXing A FAIR USE UNDER COPYRIGHT LAW?, CONG. RES. SERV. REP. NO. RS22356, at CRS-2 (2005) (explaining the fair use question in the Google Book Project is slightly different than that faced by MP3.com because the copyright holder could "opt out" from having the work appear on Google's site. "After some academic and commercial publishers objected to the Library Project, Google took a brief hiatus from scanning to allow publishers time to identify works that they, i.e., the copyright holders, do not want to be included in the digital database. This has been referred to an 'opt out' plan.").

139. See 17 U.S.C. $§ 107$ (2000).

Notwithstanding the provisions of sections 106 and 106A, the fair use of a copyrighted work, including such use by reproduction in copies or phonorecords or by any other means specified by that section, for purposes such as criticism, comment, news reporting, teaching (including multiple copies for classroom use), scholarship, or research, is not an infringement of copyright. In determining whether the use made of a work in any particular case is a fair use the factors to be considered shall include-

(1) the purpose and character of the use, including whether such use is of a commercial nature or is for nonprofit educational purposes;

(2) the nature of the copyrighted work;

(3) the amount and substantiality of the portion used in relation to the copyrighted work as a whole; and

(4) the effect of the use upon the potential market for or value of the copyrighted work.

The fact that a work is unpublished shall not itself bar a finding of fair use if such finding is made upon consideration of all the above factors.

140. See Campbell, 510 U.S. at 574; Harper \& Row Publishers, Inc., 471 U.S. at 561. 
superseding)."

As for the second prong, the nature of the works will vary. Poets may be concerned that even a small portion of a book could reproduce their entire creative work, while academic works will be more widely available, so the second factor is unhelpful. ${ }^{142}$ As to the third factor, the amount taken is the entirety of the work, thus favoring the plaintiffs. ${ }^{143}$ As often is the case, the outcome could turn on the fourth prong - the effect on the potential market for the copyrighted work, and the potential is certainly there. ${ }^{144}$ The digitization could have been licensed for a fee. The online snippets might have a discrete market value and Google should admit that access to the database has significant economic value to improve its search algorithms, speech recognitions software, and other products. ${ }^{145}$ The potential market could be quite large in the aggregate. For any one author or publisher, the benefits may be modest and potentially market speculative, but taken as a class, the market becomes quite significant. ${ }^{146}$

Publishers were rightly concerned that a fair use court determination would turn copyright "on its head," requiring copyright owner to object as a precondition of enjoining infringement. ${ }^{147}$ But these are topsy-turvy times for which Google's opt out provision could well satisfy the general anti-copyright sentiment of the public. Still, Google's honeymoon as the only beloved corporate behemoth has been fading. ${ }^{148}$ If the Book Project were perceived as a cynical tool to sell advertising, then Google would be seen as usurping a market the publishers should have been able to license. If Google could actually make a significant profit, then it should license the works, which is the essence of the fair use analysis for commercial reproduction. The fair use analysis suggests that the Google Book Search database should be licensed. Therefore, the parties attempted settlement, and

141. William F. Patry \& Richard A. Posner, Fair Use and Statutory Reform in the Wake of Eldred, 92 CAL. L. REV. 1639, 1649 (2004) (emphasis in original).

142. Compare Basic Books, Inc. v. Kinko's Graphics Corp., 758 F. Supp. 1522, 1533 (S.D.N.Y. 1991) (finding that "fictional works ... require more protection"), with Princeton Univ. Press v. Mich. Document Servs., Inc., 99 F.3d 1381, 1405 (6th Cir. 1996) (stating that "factual compilations ... may be used more freely").

143. See Harper \& Row, Publ'rs, Inc., 471 U.S. at 564-65 (discussing the quantitative and qualitative importance of fair use).

144. Id. at 566 ("This last factor is undoubtedly the single most important element of fair use.").

145. See id. at 564-65.

146. See id.

147. See Jeweler, supra note 136.

148. See generally Sherwin Siy, Google Book Search Lawsuit Settled, Fair Use Questions Remain: Settlement Proposes Book Rights Registry, PuBlic KNOwLEdGE, Oct. 28, 2008, http://www.publicknowledge.org/node/1828. 
the antitrust concerns began. ${ }^{149}$

Proponents of the Google Book Search settlement point to the societal benefits. Mark Lemley, a highly regarded intellectual property professor at Stanford and a lawyer for Google, explains the benefits as follows:

The settlement will permit Google to digitize most books published in the U.S. Members of the public will have access to electronic copies of previously unavailable works: It will be possible to search the content of the books for free, and to preview full pages from out-of-print books for free, allowing members of the public to find the books and the information they need. People who decide they want a book for themselves will be able to buy a digital version that they can read online. Libraries will be given licenses to provide free, complete access to outof-print books at terminals in their buildings. And institutions will be able to buy subscriptions to vast catalogs of works. The public gets access to works that have, as a practical matter, been unavailable for years or decades and have never been searchable; authors and publishers get revenue from works that had long since stopped generating any. The result is clearly beneficial to all concerned. ${ }^{150}$

Lemley's analysis, however, does not address the antitrust issues involved with Google's position in this system. ${ }^{151}$ Nor does it address the costs associated with these benefits. ${ }^{152}$

One cost associated with the benefit is borne by the rights holders to so-called orphan works - those copyrighted books for which the rights holder cannot be identified. ${ }^{153}$ In some cases, the orphan works are created when publishers go out of business without assigning their copyrights; in other cases orphan works arise from poorly managed estates, or in other situations where the rights transfers are forgotten, lost or mishandled. ${ }^{154}$ In these cases, the party with the legal right to enforce the copyright is unknown, thus making it all but impossible for publishers to ask for permission to use these works. ${ }^{155}$ Parties who respect copyright law cannot find a

149. Mark A. Lemley, An Antitrust Assessment of the Google Book Search Settlement, available at http://ssrn.com/abstract=1431555 (click "one click Download") (last visited Aug. 17, 2009).

150. Id.

151. See generally id.

152. See generally id.

153. See Samuelson, supra note 5.

154. See id.

155. See id. 
legitimate copyright holder from whom to license the rights; infringers can act with impunity if they dare. ${ }^{156}$

Despite suggestions to the contrary, ${ }^{157}$ the experience of many entertainment attorneys may bear out the proposition that orphan works do not actually dominate the out-of-print market. In many situations, the copyright has descended to multiple family members by will or intestate succession. These family members have limited incentive to police the copyrights of out-of-print works unless the book suddenly becomes the focus of a possible film deal or other high-value transaction. In most cases, the rights holders for out-of-print books are known; they just are not interested. ${ }^{158}$

From an antitrust perspective, the settlement provides Google a unique market position to be free of the risk of litigation for all orphan works. ${ }^{159}$ Google will be the only company that can lawfully sell the orphan works or monetize advertising related to them. ${ }^{160}$ Every other company that elects to do so risks the orphan finding a parent. The Google Book Search highlights the orphan works problem and should encourage rights owners to seek their rights with the lure of obtaining lost revenue. ${ }^{161}$ Part of the settlement requires Google to support a non-profit, collective rights organization called the Book Rights Registry (BRR), who would collect and distribute the revenue. ${ }^{162}$ The BRR is required to provide provenance information about the works claimed, further reducing the scope of the orphan works problem. ${ }^{163}$ If the revenue is significant, the number of

156. See id.

157. Professor Samuelson suggests that orphan works are "most" of the seventy percent of the books in the Book Search repository. But that appears to conflate books for which the transaction costs of enforcing the copyright outweighs the value of the copyright with those works which have no one able to enforce their rights. Id.

158. See id.

159. See Samuelson, supra note 5.

160. Amended Settlement Agreement, supra note 117, at $\S 6.3(\mathrm{a})(\mathrm{i})(1)$ (noting that Google will not receive the authors' proceeds because these funds are segregated into the Books Rights Registry).

161. See Samuelson, supra note 5.

162. See Google.com, Amended Settlement Overview, https://sites.google.com/a/pressatgoogle.com/googlebookssettlement/revisedsettlement/SettlementModificationsOverview.pdf (last visited Jan. 20, 2010).

The amended settlement agreement requires the Book Rights Registry to search for rightsholders who have not yet come forward and to hold revenue on their behalf. The settlement now also specifies that a portion of the revenue generated from unclaimed works may, after five years, be used to locate rightsholders, but will no longer be used for the Registry's general operations or redistributed to other rightsholders.

163. Id. 
phantom works will shrink. If the revenue is not significant, there is no market to monopolize.

A legislative or judicial modification could further improve the situation. ${ }^{164}$ A second class action lawsuit or Congressional act should provide a safe harbor for any publisher that wishes to publish a work from the BRR, which has not had its copyright owners identified following the five years that royalties were collected on behalf of the work. Such a safe harbor would protect publishers if the rights holders ever come forward. Such a solution would negate the cultural, rather than legal, monopoly that Google's presence in the Book Search provides. ${ }^{165}$

While there is no doubt that Google will receive some network effect benefits from the orphan works, the scope of these rights is trivial to the overall publishing market. This should not be the source of antitrust concerns. The real value in improving the search algorithms and other products flows from the scope of the database, which is largely built by

publishers that have acceded to the class action settlement, as well as physical access to the public domain works in the collection. ${ }^{166}$

A different aspect of the case, however, does raise more serious antitrust considerations. Pursuant to the proposed settlement, "Google agreed to turn over 63 percent of the revenues and data regarding use and sales to a 'Registry' that would distribute the funds to copyright holders."167 At the time of the initial proposed settlement, the U.S. Department of Justice raised antitrust and other concerns. ${ }^{168}$ "First, through collective action, the Proposed Settlement appears to give book publishers the power to restrict price competition. Second . . . other digital distributors may be effectively precluded from competing with Google in the sale of digital library prod-

164. See id. ("[T] he settlement agreement takes one important step towards opening up access to unclaimed books. In the meantime, we [Google] continue to encourage legislation that provides meaningful avenues for any entity to use these [orphan] works.").

165. See Derek Slater, Google Book Search Settlement and Access to Out of Print Books, June 2, 2009, http:/googlepublicpolicy.blogspot.com/2009/06/google-book-search-settlementand.html (last visited Aug. 16, 2009) ("Under the settlement Google will be able to open up access to truly orphaned books ... [ $\mathrm{t}$ ] he need for comprehensive orphan works legislation is not diminished.").

166. See generally Richard Thaler \& CASS Sunstein, Nudge: IMPROVING DeCisions ABOUT HEALTH, WEALTH, AND HAPPINESS (Caravan 2008) (designating the opt out for the class has undoubtedly helped Google win over these publishers).

167. Timothy J. Brennan, The Proposed Google Book Settlement: Assessing Exclusionary Effects, COMPETITION POLICY InT'L: The ANTITRUST Chron., Oct. 2009, rel. 2 at 2.

168. See generally Statement of Interest by the U.S. Dept. of Justice Regarding the Proposed Settlement, supra note 118, at 27 (noting also that the DOJ raised concerns related to the representation of the class, which are important to the litigation but less relevant here to the characterization of Google and its conduct). 
ucts and other derivative products to come."169

The Justice Department's characterization is accurate and has remained unaddressed by the amendment to the proposed settlement. ${ }^{170}$ The proposed settlement allows Google, the Authors Guild, and the Association of American Publishers to agree on a pricing mechanism for digital works. ${ }^{171}$ For example, the settlement allows Google to set an institutional fee for access to the collected database on a full-time-equivalency (FTE) basis. ${ }^{172}$

The economic terms for Institutional Subscriptions of Books will be governed by two objectives: (1) the realization of revenue at market rates for each Book and license on behalf of Rightsholders; and (2) the realization of broad access to the Books by the public, including institutions of higher education. Plaintiffs and Google view these two objectives as compatible, and agree that these objectives will help assure both long-term revenue to the Rightsholders and accessibility of the Books to the public. ${ }^{173}$

To the extent that the Authors Guild and the Association of American Publishers agrees with Google that broad access and maximizing revenue are compatible, they are engaging in behavior that should be questioned under the Sherman Act. ${ }^{174}$ The goal of authors and publishers is to maximize revenue, which may be achieved by raising prices or by lowering prices to encourage greater adoption. In either case, the activity of combining the class action of publisher and authors with Google is a massive agreement to set prices. This fits uncomfortably within the competitive framework by: "(1) the creation of an industry-wide revenue-sharing formula at the wholesale level applicable to all works; [and] (2) the setting of default prices and the effective prohibition on discounting by Google at the retail level ...."

Similarly, digital copies of books may be sold at a price "to be determined by an algorithm (the "Pricing Algorithm") that Google will design to find the optimal price for each such Book in order to maximize revenues

169. Id. at 17.

170. See Amended Settlement Agreement, supra note 117, at $\S 4.1$ (a)(iii).

171. Id.

172. $I d$.

173. $I d$. at $\S 4.1(\mathrm{a})(\mathrm{i})$.

174. 15 U.S.C. $\S \S 1-2$ (2008); see Statement of Interest by the U.S. Dept. of Justice Regarding the Proposed Settlement, supra note 118, at 17 ("these features of the Proposed Settlement bear an uncomfortably close resemblance to the kinds of horizontal agreements found to be quintessential per se violations of the Sherman Act.").

175. Id. 
for the Rightsholder for such Book . ..."176 This optimization and maximization allows Google to quantify the market for books based on sales data and other information that private publishers could never share with one another. Amendments to the provision imply that the pricing will be based on comparisons of each book to the market rather than a dynamic database (which would create a further pricing advantage for Google) but the requirement that price data be "historical" will not have pro-competitive effects. ${ }^{177}$ The optimization is unlikely to be in furtherance of price competition or the best interests of the consumer public.

Contrast the proposed Google settlement with the settlements involving ASCAP and BMI. ${ }^{178}$ In the case of the consent action involving the performing rights societies, the court administrating the consent decree retains jurisdiction over the competitiveness of the licenses. ${ }^{179}$ Unlike the Google settlement, ASCAP and BMI are not left to set the market prices without supervision. ${ }^{180}$ "Although, under the terms of the BMI Consent Decree, BMI bears the burden of establishing the reasonableness of its rates, the setting of appropriate rates remains the responsibility of the District Court." 181

Absent this continuing supervision, the ability of the parties collectively — or Google on the parties' behalf - to set the prices for digital content appears to reach the same anticompetitive heights as ASCAP and BMI meet with regard to public performances. The court's failure to recognize this in its preliminary approval is more likely to be the source of the Justice Department's interest than concern for orphan works. While the consent decree involving ASCAP and BMI suffers from excessive judicial entanglement, it has created a mechanism for fair licensing and public accountability for collectively managed private intellectual property resources. This is the accountability missing from the current proposed settlement. Worse yet, the internal dispute process is subject to a blanket of confidentiality, further hiding the mechanisms of the content pricing. ${ }^{182}$ The move towards a collective rights arrangement is in the settlement. The BRR al-

176. Amended Settlement Agreement, supra note 117, at $\S 4.2$ (b)(i)(2).

177. Id.

178. United States v. Broad. Music, Inc., 426 F.3d 91, 93 (2d Cir. 2005) ("Because of the inherently anti-competitive conditions under which BMI and ASCAP operate, they are regulated by court-approved consent decrees.") (citing United States v. ASCAP, 1940-43 Trade Cas. (CCH) I 56,104 (S.D.N.Y. 1941), as amended, United States v. ASCAP, 1950-51 Trade Cas. (CCH) ף 62,594 (S.D.N.Y. 1950)).

179. Id.

180. Id.

181. Id. at 95 .

182. See Amended Settlement Agreement, supra note 115, at $\S \S 9.1,9.8$. 
ready acts as an author's rights society, which will encourage membership through payments. ${ }^{183}$ This is only an interim step, however, for "the settlement does not directly confer on BRR the right to license any books." 184

As with other concerns, Google faces scrutiny over the Google Book Search in many countries, such as Germany, France and China. ${ }^{185}$ The outcomes and solutions are likely to vary considerably from country to country. In most countries, the performing rights societies are government agencies, so the ASCAP/BMI consent decree is unique in the world. As such, this proposed resolution is unlikely to be adopted by other nations. The Internet may be global, but nations remain territorial and apply their laws accordingly. Hopefully, the Justice Department will insist that the court exercise far greater control over the pricing and other collusive aspects of the proposed settlement, substituting its own authority for that of the American Arbitration Association.

\section{COPYRIGHT ISSUES STILL AT STAKE}

Even if the orphan book issues are economically overstated by critics, the Book Search Project and the massive digitization continues to have significant copyright implications. The first is simply the existence of the project itself. By its very nature, Google's action of copying first and then negotiating only once it held a valuable corpus of content simply flies in the face of international copyright law and ethical corporate governance. In essence, Google's approach has been one of "too big to jail" - an approach that has thus far succeeded in the U.S. but is less welcome in other countries. ${ }^{186}$ David Drummond, Google's Senior Vice President of Corporate Development and Chief Legal Officer, explains that the "settlement will create an educational, cultural, and commercial platform to expand access to millions of long-forgotten books for anyone in the United States. It will enrich our country's cultural heritage and intellectual strength [in the global economy]."187 Drummond rationalizes that copying books is no different

183. Id. at $\S \S 6.6,6.7$.

184. Samuelson-Manuscript, supra note 115, at 10, n. 69.

185. Andrew Jacobs, Google Apologizes to Chinese Authors, N.Y. TIMES, Jan. 12, 2010, at B3 ("Google has agreed to hand over a list of books by Chinese authors that it has scanned in recent years . . . in an apparent effort to placate writers who say their works were digitized without their permission. ... Google also apologized for any misunderstanding that might have angered authors ....").

186. See id.

187. Competition and Commerce in Digital Books: Hearing Before the H. Comm. on the Judiciary, 111th Cong. 5 (2009) (testimony of David Drummond, Senior Vice President of Corporate Development and Chief Legal Officer of Google, Inc.). 
than indexing web content ${ }^{188}$ - a deeply cynical analysis hardly consistent with a company that strives to do no evil. If the company truly believes its actions are beyond reproach from a copyright standpoint, then the choice to settle does not reflect good corporate stewardship. If the company is choosing to settle a copyright case it knows it can win because of the antitrust immunity it affords, then the public is undoubtedly the loser. Only if the fair use argument is indeterminable does Google have an honorable reason to settle the litigation, a position the Chief Legal Officer seems unwilling to concede.

Getting past the predatory intent, there is a second shadow thrown by the decision to settle the litigation. The settlement creates another topsyturvy result to fair use, making the printing of pages from Google public access terminals subject to a printing fee even if the same material printed elsewhere would be treated as fair use. ${ }^{189}$ This creates a normative change regarding the expectations of publishers to capture the photocopy revenue that has traditionally been considered fair use. ${ }^{190}$ This normative expectation will undoubtedly delight publishers - the beneficiaries of the price setting - but actually undermine the very fair use values Google aspires to protect. Google will not be the only source for some of these books, but the network effect of Google's growing content empire may threaten meaningful competition. As a result, Google's size may rewrite fair use in unexpected and unintended ways.

The impact of "too big to jail" creates an additional copyright policy concern. If the settlement approach creates a precedent, it will encourage other copyright predators to seek sufficient network effects in order to overcome copyright owners' objections to the use of their content. In fact, this strategy may already be observed in Viacom v. YouTube. ${ }^{191}$ As discussed infra, Google's size and prominence changed YouTube's future and gave the company the resources to avoid the injunctive relief that ended Napster, Grokster, and many others. ${ }^{192}$ The implication that with sufficient

188. Id.

189. Amended Settlement Agreement, supra note 117, at § 4.8(a)(ii); see SamuelsonManuscript, supra note 115, at 1.

190. Princeton Univ. Press, 99 F.3d at 1387; Am. Geophysical Union v. Texaco Inc., 60 F.3d 913, 931 (2d Cir. 1994) (noting that photocopying is not fair use when done on an institution-wide basis); Williams \& Wilkins Co. v. United States, 487 F.2d 1345, 1352-53 (Ct. Cl. 1973), aff'd by an equally divided court, 420 U.S. 376, 376 (1974); Basic Books, Inc. v. Kinko's Graphics Corp., 758 F. Supp. at 1535.

191. Complaint at 2, Viacom Int'1. Inc. v. YouTube, Inc. (S.D.N.Y. Mar. 13, 2007) (No. 1:07 CV02103), 2007 WL 775611. See infra note 232 and accompanying text.

192. E.g., MGM v. Grokster, 545 U.S. 913 (2005); In re Aimster Copyright Litig., 334 F.3d 643, 645-46 (7th Cir. 2003); A\&M Records v. Napster, Inc., 239 F.3d 1004, 1004 (9th Cir. 
network effects a party can rewrite copyright may explain the seemingly awkward inclusion by Drummond that the settlement will "preserve Congress's role in setting copyright policy." 193

How does the settlement reinforce the congressional role in copyright? Drummond's testimony on behalf of Google does not actually answer this question, but rather states " $[\mathrm{t}]$ he settlement does not establish new copyright law; it is not even a determination on the merits of copyright law. All the settlement represents is the means by which the class of rights holders decided to resolve the lawsuit." "194 As such, Drummond both attempts to placate those at the congressional hearing, and, at the same time, to acknowledge that the center for the copyright balance has moved to Google. ${ }^{195}$

Copyright policy has always included a balancing of competing public and industry interests regarding the copyright industries. ${ }^{196}$ Nonetheless, the balancing has gone on within the halls of Congress rather than the campuses of Silicon Valley. ${ }^{197}$ If copyright policy can be determined by a single, successful player, then the other copyright industries, as well as the public, may someday be at risk.

\section{TRADEMARK BATTLES AROUND THE GLOBE}

Antitrust and copyright issues are not Google's only international concerns. ${ }^{198}$ Being the largest Internet advertiser cannot be easy. Google finds itself defending its intellectual property and business practices around the globe. ${ }^{199}$ The practices are not uniform, yet every act of customization

2001).

193. Competition and Commerce in Digital Books: Hearing Before the H. Comm. on the Judiciary, 111th Cong. 5 (2009) [hereinafter Hearing on Competition and Commerce in Digital Books] (testimony of David Drummond, Senior Vice President of Corporate Development and Chief Legal Officer of Google, Inc.).

194. Id.

195. Hearing on Competition and Commerce in Digital Books, supra note 193, at 7-9.

196. See, e.g., Russell J. Anderson, Jr., Return of the Guilds: A Reflection on the Domestic and International Implications of Eldred v. Ashcroft, 12 U. BALT. INTELL. PROP. L.J. 49, 49 (2003); Christopher M. Bruner, Culture, Sovereignty, and Hollywood: UNESCO and the Future of Trade in Cultural Products, 40 N.Y.U. J. INT'L L. \& POL. 351 (2008); Mark S. Nadel, How Current Copyright Law Discourages Creative Output: The Overlooked Impact of Marketing, 19 BERKELEY TECH. L.J. 785 (2004).

197. See, e.g., Hearing on Competition and Commerce in Digital Books, supra note 193, at 5-6 (providing an example of a Google representative appearing before Congress, the author includes testimony of David Drummond, Senior Vice President of Corporate Development and Chief Legal Officer of Google, Inc.).

198. See Google Annual Report, supra note 8, at 25.

199. Id. 
raises concerns of local censorship. According to Google's 2009 10-K:

Companies have filed trademark infringement and related claims against us over the display of ads in response to user queries that include trademark terms. The outcomes of these lawsuits have differed from jurisdiction to jurisdiction. We currently have three cases pending at the European Court of Justice, which will address questions regarding whether advertisers and search engines can be held liable for use of trademarked terms in keyword advertising. We are litigating, or have recently litigated similar issues in other cases, in the U.S., Australia, Austria, Brazil, Chile, China, France, Germany, Israel, Italy, Taiwan, and the United Kingdom. ${ }^{200}$

\section{Adwords, Meta Tags, AND Hidden TeXt}

Courts in different cases and jurisdictions have struggled to determine whether the use of a trademark by an unauthorized party, to drive web traffic to its site, constituted trademark infringement. ${ }^{201}$ No court, for example, has suggested that the use by a consumer of a trademark in the search for products would generate trademark infringement by that consumer. If a consumer uses "Kleenex" as a search term, the search engine will return hits for Kleenex ${ }^{\circledR}$ products, Kleenex ${ }^{\circledR}$ retailers, news stories where the word was used, and less relevant uses. Under the trademark first sale doctrine, product resellers should face no legal limits from the trademark owner for merely "displaying" the availability of the brand at its site. ${ }^{202}$ Courts have found liability, however, if the trademark is added to the domain name. ${ }^{203}$

200. $I d$.

201. See Sebastian Int'l, Inc. v. Longs Drug Stores Corp., 53 F.3d 1073 (9th Cir. 1995)

(explaining the disagreement between Ninth and Fifth Circuits).

202. Id. at 1076.

It is the essence of the 'first sale' doctrine that a purchaser who does no more than stock, display, and resell a producer's product under the producer's trademark violates no right conferred upon the producer by the Lanham Act. When a purchaser resells a trademarked article under the producer's trademark, and nothing more, there is no actionable misrepresentation under the statute.

Id.

203. E.g., KP Permanent Make-Up, Inc. v. Lasting Impression I, Inc., 543 U.S. 111, 123 24 (2004); PACCAR Inc. v. TeleScan Techs., L.L.C., 319 F.3d 243, 258 (6th Cir. 2003) (finding that Plaintiff "PACCAR demonstrated a strong likelihood of success . . . of its trademark infringement claim" and remanded for further proceedings); People for the Ethical Treatment of Animals v. Doughney, 263 F.3d 359, 362 (4th Cir. 2001); Brookfield Commc'ns, Inc. v. W. 
A slightly different question arises if a competitor uses a trademark to generate ad links without otherwise using the competitor's trademark on its website. Specifically, one of the key sources of Google's income flows from selling text ads online, which appear in a box either on the right side of the search results or above the search results. ${ }^{204}$ In a series of cases, including Rescuecom Corp. v. Google, Inc., ${ }^{205}$ two of Google's services have come under increasing judicial scrutiny, regarding the rights of Google to sell access to a trademark holder's mark.

AdWords is Google's program through which advertisers purchase terms (or keywords). When entered as a search term, the keyword triggers the appearance of the advertiser's ad and link. An advertiser's purchase of a particular term causes the advertiser's ad and link to be displayed on the user's screen whenever a searcher launches a Google search based on the purchased search term. Advertisers pay Google based on the number of times Internet users "click" on the advertisement, so as to link to the advertiser's website. . . . ${ }^{206}$

In addition to Adwords, Google also employs Keyword Suggestion Tool, a program that recommends keywords to advertisers to be purchased. The program is designed to improve the effectiveness of advertising by helping advertisers identify keywords related to their area of commerce, resulting in the placement of their ads before users who are likely to be responsive to it. . . Once an advertiser buys a particular keyword, Google links the keyword to that advertiser's advertisement. The advertisements consist of a combination of content and a link to the advertiser's webpage. Google displays these advertisements on the search result page either in the right margin or in a horizontal band immediately above the column of relevance-based search results. These advertisements are generally associated with a label, which says "sponsored link" . . ${ }^{207}$

$\ldots$

... Google's objective in its AdWords and Keyword Suggestion

Coast Entm't Corp., 174 F.3d 1036 (9th Cir. 1999); Panavision Int'l, L.P. v. Toeppen, 141 F.3d

1316 (9th Cir. 1998); Cardservice Int'1, Inc. v. McGee, 950 F. Supp. 737, 743 (E.D. Va. 1997);

Green Prods. Co. v. Independence Corn By-Prods. Co., 992 F. Supp. 1070, 1082 (N.D. Iowa 1997).

204. Rescuecom Corp. v. Google Inc., 562 F.3d 123, 126 (2d Cir. 2009).

205. Id. at 123 .

206. Id. at 125 .

207. Id. at 126 . 
Tool programs is to sell keywords to advertisers. ${ }^{208}$

In early jurisprudence on the issue, the threshold analysis focused on whether the sale of the keyword was a "use in commerce" of the plaintiff's trademark. $^{209}$ The "use in commerce" language in the Lanham Act has a number of potentially different meanings. ${ }^{210}$ Until this year, courts in the Second Circuit had interpreted the term to require that the trademark appear on the potential infringer's page; merely purchasing the keyword for promotion of a sponsored link was insufficient. ${ }^{211}$ Other circuits had not followed this interpretation and found the sale of the keywords was sufficient to be "in commerce." 12 In a dispute between GEICO and Google, for example, the Virginia district court found the sale of the keyword sufficient to establish the trademark was "in commerce" and "in connection with the sale, offering for sale, distribution, or advertising." 213

The Gilson trademark treatise agreed with this broader interpretation. ${ }^{214}$ "The 'use in commerce' requirement means that the mark has traveled in or affected interstate commerce and 'commercial use' means that the use attempts to influence consumers to purchase goods or services." 215 In a similar case involving GoTo.com, U.S. district courts in New Jersey found that the use of trademarks as suggested keywords constituted a use

208. Id.

209. See 1-800 Contacts, Inc. v. WhenU.com, Inc., 414 F.3d 400, 406 (2d Cir. 2005).

210. See Rescuecom Corp., 562 F.3d at 131-36.

211. Regina Nelson Eng, A Likelihood of Infringement: The Purchase and Sale of Trademarks as Adwords, 18 ALB. L.J. SCI. \& TECH. 493, 505 (2008).

The rationale for relying on the definition of "use in commerce" provided in section fortyfive of the Lanham Act is flawed for several reasons. First, the courts are applying the definition of "use in commerce" outside of the context for which it was intended. Second, infringement under the Lanham Act does not require a visual use of the trademark. Third, trademark keying is a use of a trademark in a manner that indicates the source or origin. Fourth, the Rescuecom v. Google court's analogy to retail store product placement is flawed. Finally, the courts failed to consider that the invisible use of trademarks in metatags has long been considered a trademark use.

Id.

212. E.g., J.G. Wentworth S.S.C. Ltd. LP v. Settlement Funding LLC, 85 U.S.P.Q.2d (BNA) 1780, 1785 (E.D. Pa. 2007); Int'l Profit Assocs., Inc. v. Paisola, 461 F. Supp. 2d 672, 677 (N.D. Ill. 2006); Edina Realty Inc. v. TheMLSonline.com, 80 U.S.P.Q.2d (BNA) 1039, 1042 (D. Minn. 2006); Gov't Emps. Ins. Co. v. Google, Inc., 77 U.S.P.Q.2d (BNA) 1841, 1844 (E.D. Va. 2005).

213. Gov't Emps. Ins. Co., 330 F. Supp. $2 \mathrm{~d}$ at 702 (earlier proceeding) (citing People for the Ethical Treatment of Animals v. Doughney, 263 F.3d 359, 364 (4th Cir. 2001)).

214. 2 ANNE Gilson LALONDE ET AL., GiLSON ON TRAdEMARKS § 7A.09 (2009) [hereinafter GILSON].

215. Id. 
"in commerce."216 GoTo's product "solicit[ed] bids from advertisers for key words or phrases to be used as search terms, giving priority results on searches for those terms to the highest-paying advertiser." ${ }^{217}$ This met the "use in commerce" test.

GoTo makes trademark use of the JR marks in three ways. First, by accepting bids from those competitors of JR desiring to pay for prominence in search results, GoTo trades on the value of the marks. Second, by ranking its paid advertisers before any 'natural' listings in a search results list, GoTo has injected itself into the marketplace, acting as a conduit to steer potential customers away from JR to JR's competitors. Finally, through the Search Term Suggestion Tool, GoTo identifies those of JR's marks which are effective search terms and markets them to JR's competitors. Presumably, the more money advertisers bid and the more frequently advertisers include JR's trademarks among their selected search terms, the more advertising income GoTo is likely to gain. ${ }^{218}$

The Northern District of California adopted this reasoning against Google, finding that the use of the plaintiff's trademarks in the AdWords advertising program constituted a use in commerce that is likely to cause consumer confusion. ${ }^{219}$ Other courts have likewise found that the "use in commerce" exception is no longer a barrier to trademark infringement actions. Cases in Minnesota and Virginia, for example, have tended to conflate the concepts of "use in commerce" and "commercial use" but in doing so focus on the sale of the keyword rather than its absence on the third party website. ${ }^{220}$ As a result, in those cases, the purchase of a trademark has been held to infringe the mark. ${ }^{221}$

The Second Circuit decision in Rescuecom reinforces the trend to treat the sale of keywords as a use in commerce. ${ }^{222}$ This opinion is noteworthy because of the thoughtful correction provided by the Court regarding the technical bar that had developed surrounding the term "in com-

216. 800-JR Cigar, Inc. v. GoTo.com, Inc., 437 F. Supp. 2d 273, 292 (D. N.J. 2006).

217. $I d$. at 277.

218. Id. at 285 .

219. Google Inc. v. Am. Blind \& Wallpaper Factory, Inc., 2007 U.S. Dist. LEXIS 32450, 20 (N.D. Cal. 2007).

220. GILSON, supra note 214, at $\S 7$ A.09 (citing J.G. Wentworth S.S.C. LP v. Settlement Funding LLC, 85 U.S.P.Q.2d 1780 (E.D. Pa. 2007); Edina Realty, Inc. v. TheMLSonline.com, 80 U.S.P.Q.2d (BNA) 1039 (D. Minn. 2006)).

221. Id.

222. Rescuecom Corp., 562 F.3d at 126-27, 131. 
merce.",223

Of course, as the decisions against Google in California and Virginia point out, the mere use of the keywords does not automatically give rise to liability for infringement. Rescuecom and Google settled their dispute following the Second Circuit decision. ${ }^{224}$ Nonetheless, the legal issues involving Google's use of keyword advertising continue.

[W] here keyword placement of . . advertising is being sold, the portals and search engines are taking advantage of the drawing power and goodwill of these famous marks. The question is whether this activity is fair competition or whether it is a form of unfair free riding on the fame of well-known marks. ${ }^{225}$

With the barrier of "in commerce" lifted, the courts must still determine whether the use by a third party constitutes a likelihood of initial interest confusion. ${ }^{226}$ The focus of this confusion is generally referred to as "initial interest confusion" because the consumer undoubtedly realizes that he has been directed elsewhere prior to the completion of the transaction. ${ }^{227}$ Nevertheless, where the goods or services directly compete and the mark is sufficiently strong, the unauthorized trademark user has effectively purchased the plaintiff's trademark for the purpose of generating customer interest from the competitor's mark. ${ }^{228}$

Initial interest confusion is still applied through the likelihood of confusion test. ${ }^{229}$ Although described differently in various circuits, the general parameters are the same in each. ${ }^{230}$ In reviewing the question, several

223. Id. at 131 .

224. Greg Piper, Early AdWords Infringement Plaintiff Drops Suit, but Concessions Unclear, WASH. INTERNET DAILY, Mar. 9, 2010 ("Rescuecom is ready to declare victory over 'Googleiath,' it said late Friday, because Google banned competitors' trademarks from appearing in ad copy a few years ago, eliminating one of Rescuecom's main complaints.").

225. Gov't Emps. Ins. Co., 330 F. Supp. 2d at 704 (quoting J. ThOMAS MCCARTHY, MCCARTHY ON TRADEMARKS \& UNFAIR COMPETITION § 25:70.1 (2004)).

226. Id.

227. Brookfield Commc'ns. v. W. Coast Entm't Corp., 174 F.3d 1036, 1063 (9th Cir. 1999); Dr. Seuss Enters., L.P. v. Penguin Books USA, Inc., 109 F.3d 1394, 1398 (9th Cir. 1997); Mobil Oil Corp. v. Pegasus Petroleum Corp., 818 F.2d 254, 257-58 (2d Cir. 1987).

228. Brookfield Commc'ns, 174 F.3d at 1065-66.

229. MARY LAFrance, Understanding TRADEMARK LAW 167-68 (2d ed. 2009). Cir. 1961)

230. Id. at 166. See, e.g., Polaroid Corp. v. Polarad Elecs. Corp., 287 F.2d 492, 495 (2d

Where the products are different, the prior owner's chance of success is a function of many variables: the strength of his mark, the degree of similarity between the two marks, the proximity of the products, the likelihood that the prior owner will bridge the gap, actual confusion, and the reciprocal of defendant's good faith in adopting its own mark, the quality of defendant's product, and the sophistication of the buyers. Even this extensive catalogue does not exhaust the possibilities - the court may have to take still other variables into account. 
factors are accorded greater significance, including: the strength of the mark, the similarity between the two marks, the good faith of the party utilizing the second mark, and actual confusion. ${ }^{231}$

The strength of the mark often dominates the outcome of these disputes. GEICO is a famous, heavily ad-supported trademark, and Rescuecom's website receives 17,000 to 30,000 hits monthly. ${ }^{232}$ The similarity of the two marks will also play an important factor, limiting even owners of famous marks from not to reaching too broadly to stop unrelated uses. ${ }^{233}$ Owners of trademarks that wish to police keywords will need to improve the survey evidence of actual confusion. The evidence presented thus far suggests the Sponsored Links do generate a great deal of confusion. ${ }^{234}$ "According to the survey results, $67.6 \%$ of test group respondents expected that they would reach GEICO's [w]eb site if they clicked on the Sponsored Links, and $69.5 \%$ thought that the Sponsored Links were either links to GEICO's site or affiliated with GEICO in some way." 235 Despite the GEICO Court's disdain for the survey, it nonetheless found these numbers sufficient to support a finding of likelihood of confusion for the Sponsored Links, though the GEICO Court felt the same survey's flaw compelled a different result for the keywords. ${ }^{236}$ Such evidence will only become more sophisticated in future cases.

The final factor, however, may become the most significant. Where Google sold trademarks to direct competitors of the trademark holder and those competitors purchased the trademarks of their direct competition for the purpose of promoting Sponsored Links when the public sought information about particular trademarks, courts are increasingly likely to find a likelihood of confusion. ${ }^{237}$ The reason is simple: the sale of trademarks for that purpose intentionally deceives the public using the search engine. ${ }^{238}$

Id.

231. LAFRANCE, supra note 229, at 168; Polaroid Corp. v. Polarad Elecs. Corp., 287 F.2d 492, 495 (2d Cir. 1961).

232. Rescuecom Corp., 562 F.3d at 125.

233. LAFRANCE, supra note 229 , at 170.

234. Gov’t Emps. Ins. Co. v. Google Inc., 77 U.S.P.Q.2d (BNA) 1841, 1846 (E.D. Va. 2005).

235. Id.

236. Id. at 1847 .

237. See, e.g., Rescuecom Corp., 562 F.3d at 125; FragranceNet.com, Inc. v. Les Perfumes, Inc., 2009 WL 4609268 (E.D.N.Y. 2009).

238. See N. Am. Med. Corp. v. Axiom Worldwide, Inc., 522 F.3d 1211, 1226 (11th Cir. 2008 ) (providing as an example that false statements made by doctors "logically would influence a [consumer's] decision to purchase the [product] over a competing machine without those qualities."). 
Other commentators have even stronger opinions:

Nonetheless, courts should broaden the interpretation to encompass the activities of Google in trademark keying in AdWords. Google is more directly involved in the infringement than those acting as service providers have historically been because Google is not merely a passive conduit for the infringing activity, but Google actually sells the trademarks to the advertisers. Google also designs the appearance and sets the location of the advertisements in a manner most likely to deceive consumers into believing they have selected an organic search result. Google just recently changed the background of the "sponsored links" that top the search results from a pastel blue to a barely noticeable pale yellow. The pale yellow background is virtually impossible to see, so even search engine users who are aware that paid advertisements appear before the search results will likely be confused. ${ }^{239}$

The alternative view is that the public does not recognize or respect brand names, such that the use of those brands in keyword searches is merely shorthand for the product category. ${ }^{240}$ But this approach undermines the entirety of trademark practice. A policy designed to encourage the public's disparagement of trademarks will reduce their value. ${ }^{241}$ A system in which searches using trademarks will not automatically convert trademarks into product categories will improve the trademark's function as a designation of source or origin for a product. ${ }^{242}$

Keywords are not the only way in which trademarks may be improperly used on the Internet. Google is often discussed in the context of meta tags because some search engines rely on matching words and their frequency for search relevancy. ${ }^{243}$ "[M] eta keywords tag . . . allows the creator of a web site to provide additional text for some search engines to index, along with the text of the web page. ${ }^{244}$ Increasingly, the use of a third

239. Eng, supra note 211 , at 516-17.

240. See generally Jonathan J. Darrow \& Gerald R. Ferrera, The Search Engine Advertising Market: Lucrative Space or Trademark Liability?, 17 TEX. INTELL. PROP. L.J. 223 (2009).

241. See id. at 235-36.

242. See generally Gregory R. Shoemaker, Comment,_Don't Blame Google: Allowing Trademark Infringement Actions Against Competitors Who Purchase Sponsored Links On Internet Search Engines Under The Initial Interest Confusion Doctrine, 58 CATH. U. L. REV. 535 (2009).

243. GILSON, supra note 214 , at $\S 7$ A.08.

244. Id. 
party's trademark in one's meta tags or in hidden text ${ }^{245}$ can give rise to trademark liability. ${ }^{246}$

The liability for use of meta tags or hidden text will arise from initial interest confusion where the introduction of the plaintiff's trademark is designed to attract business for the defendant. ${ }^{247}$ However, if the use of the meta tag accurately reflects the information on the site, then no liability should arise. ${ }^{248}$

Along with hidden text and hidden links, meta tags can be used to fool these types of search tools and create better search returns. ${ }^{249}$ Google will remove a site from its listings if it uses misleading meta tags or hidden text and links. ${ }^{250}$ Additionally, Google does not utilize meta tags or hidden text in its Page Rank algorithms. ${ }^{251}$ As a result, it is not directly involved in most meta tag lawsuits.

\section{Another Dust-Up Over CONTENT Distribution}

YouTube, a social media network for sharing video clips, has been one of the more interesting acquisitions made by Google. ${ }^{252}$ Purchased in 2006, the site was regarded as a video equivalent of Napster: an innovative technology, a cultural phenomenon, and a hotbed of copyright infringement. ${ }^{253}$ By March 2007, the film and television conglomerates had had

245. Google.com, Hidden Text and Links-Webmaster Tools Help, http://www.google.com/support/webmasters/bin/answer.py?hl=en\&answer=66353 (last visited Aug. 14, 2009). [hereinafter Webmaster Tools] (explaining that text, such as excessive keywords, can be hidden in several ways, including: using white text on a white background; including text behind an image; using CSS to hide text; and setting the font size to zero).

246. See, e.g., N. Am. Med. Corp., 522 F.3d at 1212.

247. E.g., id. at 1222, 1224; Horphag Research Ltd. v. Pellegrini, 328 F.3d 1108, 1112 (9th Cir. 2003); Promatek Indus., Ltd. v. Equitrac Corp., 300 F.3d 808, 812 (7th Cir. 2002).

248. Playboy Enters., Inc. v. Welles, 279 F.3d 796, 803-04 (9th Cir. 2002) (meta tags accurately described content of former Playboy Playmate's website). See also Faegre \& Benson, LLP v. Purdy, 367 F. Supp. 2d 1238, 1247 (D. Minn. 2005) (fair use for parody site); J.K. Harris \& Co. v. Kassel, 253 F. Supp. 2d 1120, 1127 (N.D. Cal. 2003) (fair use); Trans Union LLC v. Credit Research, Inc., 142 F. Supp. 2d 1029, 1039-40 (N.D. Ill. 2001) (fair use).

249. See Anne Gilson LaLonde, It's Still Unsafe to Use a Competitor's Trademarks in Your Meta Tags, 2008 EMERGING IsSUES 2367 (2008).

250. Webmaster Tools, supra note 245.

251. See Vitaly Freidman, Google PageRank: What Do We Know About It?, SMASHING MAGAZINE, June 5, 2007, http://www.smashingmagazine.com/2007/06/05/google-pagerankwhat-do-we-really-know-about-it/.

252. See YouTube.com, YouTube Fact Sheet, http://www.youtube.com/t/fact_sheet (last visited Mar 2, 2010).

253. See Jon Healey, Napster déjà vu?, L.A. TIMES, Nov. 26, 2006, at M3; Chris Gaither, Scaling the Heights, L.A. TIMES, Nov. 17, 2006, at C1. 
enough. Viacom International, Paramount Pictures and other plaintiffs filed a lawsuit seeking to stop the unauthorized posting of broadcast content on YouTube. ${ }^{254}$

The copyright owners claimed to have "identified more than 150,000 unauthorized clips of their copyrighted programming on YouTube that had been viewed an astounding 1.5 billion times." ${ }^{255}$ There has never been any factual dispute that at least tens of thousands of files have been uploaded to YouTube without the copyright owners' consent. The real question is whether YouTube's efforts have been sufficient under the take-down provisions of the Digital Millennium Copyright Act (DMCA) to provide it safe harbor protection from liability. ${ }^{256}$ But given the increasingly close relations Google has developed with the broadcast industry and its continuing attempt to serve as advertising distributor for television, the decision in the dispute will be largely irrelevant to the long term evolution of video media distribution. ${ }^{257}$

In the months following the initial filing of Viacom v. YouTube, a number of agreements have been made involving licensed music videos and other content on YouTube, changing the relationship among the litigants to that of business partners. ${ }^{258}$ For example, a website named Vevo.com has been under development through a joint effort of YouTube and Universal Music Group. ${ }^{259}$ Rather than serving to redefine market dominance in the entertainment field for upcoming generations, this titanic litigation is likely to merely shift money from one company to another, based on historic business practices. The result will alter the influence each litigant has at the bargaining table, but it will do little to shift the transition in media relations among content producers, distributors, and consumers.

Nonetheless, the legal interpretation of the DMCA will have a significant impact on other intellectual property companies that rely on the safe harbor provisions, and their efforts to comply. Section 512 of the Copyright Act creates a safe harbor for an Internet service provider which serves to transmit Internet traffic, temporarily cache content on its system, or host

254. Complaint, supra note 191, at 3, 5 .

255. Id.

256. 17 U.S.C. $\$ 512(2000)$.

257. See Jessica Guynn \& Meg James, Google to Sell Ads for NBC, L.A. TiMES, Sept. 9, 2008, at C1.

258. Adam Satariano \& Brian Womack, Bono Plays Matchmaker as YouTube, Universal Create Music Site, BlOOMBERG.COM, Apr. 14, 2009,

http://www.bloomberg.com/apps/news?pid=20601109\&sid=aaEHAG7vyT94\#.

259. Miguel Helft, With Advertising in Mind, YouTube and Universal Join to Create a Hub for Music, N.Y. TIMES, Apr. 10, 2009, at B3. 
content at the "direction of users." 260 The term "service provider means, [inter alia], a provider of online services or network access. . .."261 A1though this definition is not particularly illuminating, it is likely to include YouTube. YouTube serves as a host to the videos uploaded by the public. ${ }^{262}$ It provides tools to upload but does not edit or select content. ${ }^{263}$

As a result of its service provider function, YouTube will likely be immune from monetary damages or injunctive relief if it does not have knowledge of the infringing material posted by its users, does not gain a direct financial benefit from the infringing activity, and takes expeditious steps to remove the infringing material once it receives proper notice of the infringement. ${ }^{264}$

Given the scale of unauthorized traffic on YouTube's site, it is hard to imagine that a jury would believe YouTube had no knowledge of infringing activity. Indeed, like the facts in Napster, it may become clear that the bulk of YouTube traffic was focused on copyrighted material, particularly popular television clips. ${ }^{265}$ YouTube acknowledges the significant copyright infringement on the site but counters that it has been diligent in responding to notices to remove the infringing material, even when those notices did not

260. 17 U.S.C. $\S 512(2000)$.

261. Id. at $\S 512(\mathrm{k})(1)(\mathrm{B})$.

262. See YouTube Fact Sheet, supra note 250 , http://www.youtube.com/t/fact_sheet (last visited Mar. 2, 2010).

263. Id.

264. 17 U.S.C. $§ 512(c)(1)(2000)$

(c) Information residing on systems or networks at direction of users.

(1) In general.-A service provider shall not be liable for monetary relief, or, except as provided in subsection (j), for injunctive or other equitable relief, for infringement of copyright by reason of the storage at the direction of a user of material that resides on a system or network controlled or operated by or for the service provider, if the service provider-

(A) (i) does not have actual knowledge that the material or an activity using the material on the system or network is infringing;

(ii) in the absence of such actual knowledge, is not aware of facts or circumstances from which infringing activity is apparent; or

(iii) upon obtaining such knowledge or awareness, acts expeditiously to remove, or disable access to, the material;

(B) does not receive a financial benefit directly attributable to the infringing activity, in a case in which the service provider has the right and ability to control such activity; and

(C) upon notification of claimed infringement as described in paragraph (3), responds expeditiously to remove, or disable access to, the material that is claimed to be infringing or to be the subject of infringing activity.

See also Perfect 10, Inc. v. CCBill LLC, 488 F.3d 1102, 1111 (9th Cir. 2007).

265. See Napster, 239 F.3d at 1013 ("The record supports the district court's determination that as much as eighty-seven percent of the files available on Napster may be copyrighted and more than seventy percent may be owned or administered by plaintiffs.") (internal quotations omitted). 
necessarily meet the statutory requirements. ${ }^{266}$

YouTube has long said it removes such proprietary clips when owners demand it, but [in October 2007] the company took a more conciliatory stance. It announced a program under which copyright holders can provide YouTube with advance copies of their programming for identification purposes. Using new software, YouTube said, it can then automatically remove clips as users post them. ${ }^{267}$

The scale of the problem faced by YouTube is enormous. ${ }^{268}$ Were YouTube not in existence, there would be an even larger multitude of video-hosting sites, increasing the burden on a copyright holder to police the Internet.

The crux of the litigation will center on the extent to which the content owners can prove YouTube staff were "aware of facts or circumstances from which infringing activity is apparent." 69 Any quick search on YouTube will generate content that the copyright holders did not post. ${ }^{270}$ Type in a song title and many different performances of the song will appear. In such cases, not only does the copyright holder in the video have a copyright infringement claim (against the unauthorized uploader, if no one else), but in many cases, so do the composer and lyricist of the song. ${ }^{271}$

Google and YouTube continue to improve the technology to filter infringing content. ${ }^{272}$ Among the tens of thousands of files, there have undoubtedly been some notices that were misfiled and some removals that were not expeditious. On the other hand, YouTube transformed itself from a small viral company, building a business out of commercial copyrights, to a dominant Internet Web host that actively polices content. ${ }^{273}$ YouTube

266. See 17 U.S.C. § 512(c)(3) (2000); see also YouTube.com, Frequently Asked Questions, http://www.youtube.com/fact_sheet (last visited Mar. 2, 2010).

267. Thomas Mulligan, Viacom to Offer All Clips of 'Daily Show' Online, L.A. TIMES, Oct. 18, 2008, at C1.

268. See, e.g., YouTube Law Fight 'Threatens Net', BBCNEWS, http://news.bbc.co.uk/2/hi/technology/7420955.stm (last visited Mar. 12, 2010) (noting that Viacom alone identified over 150,000 unauthorized clips available on YouTube).

269. 17 U.S.C. $\S 512(\mathrm{c})(\mathrm{A})(\mathrm{ii})$ (2000).

270. See Layton \& Strickland, supra note 55.

271. Unless the rights to perform the song on television included the rights to perform the song on the Internet, the composer and lyricist have an independent cause of action.

272. See YouTube.com, YouTube Video Identification Beta, http://www.youtube.com/t/video_id_about (last visited Mar. 2, 2010).

273. See YouTube.com, YouTube Copyright Policy: Copyright Infringement Policy, http://www.google.com/support/youtube/bin/answer.py?hl=en\&answer=55772 ( last visited Mar. 9, 2010). 
will likely recognize that some of its value stemmed from the infringing activities of the company before it began working more closely with television and film companies.

\section{SitTing With Copyright On Its HeAD}

What does the ubiquity of the unauthorized content on YouTube tell us about copyright policy? Comparing the possible results in Viacom $v$. YouTube with the provisions of the Google Book Search leads to an interesting insight about copyright - the rights are not that important. In a minority of cases, copyright owners actively police their highly valuable rights, and in a few cases, thin-skinned artists may choose to over-police those rights. ${ }^{274}$ In what seems to be the overwhelming majority of cases, however, the copyright owners are comfortable allowing the unauthorized materials to remain available, even when the only transaction cost is a simple take-down notice. ${ }^{275}$

The implications from the conduct of copyright owners engaged with YouTube, the Google Book search, and other fora suggest that there may be multiple norms for copyright. The incentive for the publisher of a highly valuable work is to maximize the exploitation of that work. This may be to control the distribution or simply to garner the revenue. For example, clips from "The Colbert Report" were pulled off YouTube, but Comedy Central made them all available in an authorized manner on its own site. ${ }^{276}$ For academic authors, out-of-print authors, and many other artists, there may be a desire to give less than everything away while still choosing not to enforce the legal rights available.

The end result is a copyright policy upside down from the 1976 Copyright Act. ${ }^{277}$ Copyright owners are expected to take the first step to object to a posting on the Internet. If the objection is ignored, then the copyright owner receives the support of the law. But the copyright owner can choose not to act. ${ }^{278}$

274. See Margena A. Christian, Prince Continues His Purple Reign at 50, JET, June 23, 2008 , at 60 .

275. See Katie Allen, Google Seeks to Turn a Profit from YouTube Copyright Clashes, GUARDIAN.CO.UK, Nov. 1, 2009, http://www.guardian.co.uk/technology/2009/nov/01/googleyoutube-monetise-content.

276. Mulligan, supra, note 267.

277. See Gigi B. Sohn, Address at the New Media and the Marketplace of Ideas Conference at Boston University Collge of Communication: Six Steps to Digital Copyright Sanity: Reforming a Pre-VCR Law for a YouTube World (Oct. 26, 2007) (transcript available at http://www.publicknowledge.org/pdf/gbsohn-speech-20071026.pdf).

278. Id. Contra Creative Commons, What is CC?, 


\section{SABOTAGE, ESPIONAGE, AND CENSORSHIP.CN}

Perhaps the most salient example of the peculiar times facing Google comes from China, which has been involved in controversies surrounding the international Book Search Project, claims of computer hacking and espionage, censorship, Google's refusal to sell into China, and a belated refusal to comply with local censorship laws. ${ }^{279}$ Google's China story begins with its launch of Google.cn. ${ }^{280}$ According to Google's Chief Legal Officer, David Drummond, Google "launched Google.cn in January 2006 in the belief that the benefits of increased access to information for people in China and a more open Internet outweighed our discomfort in agreeing to censor some results." 281

The initial decision to provide Internet service to China, while knowing of the obligation to be complicit in censorship and surveillance of citizens, raises ethical issues that every company doing business internationally needs to acknowledge. ${ }^{282}$ This should not suggest that companies are unethical for conducting such business. Google undertook the launch of Google.cn mindful of the ethical tensions involved, and should be recognized for its open discourse regarding the challenging ethical dilemma. ${ }^{283}$ At the time, Google co-founder Sergey Brin noted the decision "compromised our principles. $" 284$ So the decision to enter China, while not necessarily evil, was certainly an uncomfortable one.

http://creativecommons.org/about/what-is-cc (last visited Apr. 18, 2010) (binding the copyright owner to allow all third party uses in the manner specified by the license. The choice not to enforce the copyright has far less precedential value on the owner's property interests than the choice to adopt a particular Creative Commons license).

279. See generally Posting of David Drummond to the Official Google Blog, A New Approach to China, http://googleblog.blogspot.com/2010/01/new-approach-to-china.html (Jan. 12, 2010, 15:00 EST).

280. See generally id.

281. Id. ("At the time we made clear that "we will carefully monitor conditions in China, including new laws and other restrictions on our services. If we determine that we are unable to achieve the objectives outlined we will not hesitate to reconsider our approach to China."') (emphasis in original).

282. James Heffernan, An American in Beijing: An Attorney's Ethical Considerations Abroad with a Client Doing Business with a Repressive Government, 19 GEO. J. LEGAL ETHICS 721,723 (2006) (stating that a lawyer has a duty "not to advise the client to violate the law under Model Rule 1.2(d) . . . [but] . . u under Model Rule 2.1 . . could permit the attorney to compel the client to follow human rights law by bringing other considerations to the client's attention").

283. See Kirsten E. Martin, Business Roundtable Institute for CORPORATE ETHICS, CASE BRI-1004: GOOGLE, INC., IN CHINA 15 (2006), available at http://www.darden.virginia.edu/corporate-ethics/pdf/BRI-1004.pdf.

284. Michael Sheridan, China's Great Internet Stand-Off, SundAY TIMES (LONDON), Jan. 17,2010 , at 8 . 
Since then the situation has worsened. In December 2009, Google and twenty or more U.S. companies were targeted with sophisticated cyber attacks. ${ }^{285}$ Google and the U.S. State Department publicly suggested that the Chinese government is to blame for the attacks, either directly or through its tacit approval, ${ }^{286}$ noting that "a primary goal of the attackers was accessing the Gmail accounts of Chinese human rights activists."287

Other reports suggest a broader array of targets including, "Northrop Grumman, the US [defense] contractor; Dow, the chemicals giant; Adobe Systems, the software firm; and an American law firm acting for Cybersitter, a firm pursuing a $\$ 2.2$ billion lawsuit against China." 288 While these targets may include dissidents, it is undoubtedly not the only goal of China's cyber attack policy. In fact, "Joel Brenner, former director of the Office of the National Counterintelligence Executive, has identified China as the origin point of extensive malicious cyber activities that target the United States." 289 Comparing the attacks suffered in December with the ongoing reports of China's cyber-intrusions, it is unlikely that the goal was merely to harass Chinese dissidents (though the likelihood that this was part of the activity is certainly true enough).

The characterization of the motive for the attacks does not lessen the precarious relationship between Beijing and Google-or Beijing and Washington - nor does it take away the evidence of the very real threat posed by the totalitarian regime. It does, however, suggest that Google may want to depict its response as moral outrage rather than calculated economics. Google's economic exposure to China is presently calculated at roughly five percent of its income, with revenues ranging from $\$ 300$ to $\$ 600$ million. ${ }^{290}$ Google runs a distant second in the online search business

285. Drummond, supra note 279.

286. Nicholas Kralev, U.S. Seeks Explanation on Cyberattacks on Google, WASH. TIMES, Jan. 14, 2010, at A07 ("Both the administration and Google suggested that such a wellcoordinated and sophisticated attack could not have taken place without the government's knowledge.").

287. Drummond, supra note 279.

288. Michael Sheridan, China's Great Internet Stand-Off, SUNDAY TIMES (LONDON), Jan. 17, 2010, at 8 .

289. U.S.-CHINA ECONOMIC AND SECURITY REVIEW COMM'N, 111TH CONG., REPORT TO CONG., 1st. Sess., at 167 (2009).

Cyber attacks that originate in China can defy easy classification; some malicious activity appears to originate from private hacking groups, while other activity is almost certainly state sponsored. The latter . . . can be recognized to a certain extent by two important factors. First, cyber incidents leave behind signatures that can, with forensic analysis, sometimes reveal the affiliation of the responsible actors to a reasonable degree of certainty.

Id. at 169 .

290. Kralev, supra note 284, at A07. 
to Baidu, which has seventy-five percent of the market compared to Google's twenty percent. ${ }^{291}$

Once it adds the sales of its Android cellular phones, its potential revenue and its potential exposure increase dramatically. ${ }^{292}$ As a result, one of Google's initial responses has been to delay the introduction of the Android phone operating system in China. ${ }^{293}$ Another of its responses has been to eliminate censorship of Google.cn, which is a condition of its operations in China. ${ }^{294}$

Do these responses stem from Google's moral outrage at the blatant attacks on Chinese dissidents, or are they the business calculations of a company threatened by trade secret theft and the potential risk of outright sabotage ${ }^{295}$ Increasingly, the analysis of the attack is focusing less on the dissidents and more on the damage that may have been caused by the attacks and the potential for the attackers to have inserted their software code into the operating software of the targets. ${ }^{296}$ Such code could create longterm security breaches or be used for later sabotage $;{ }^{297}$ accordingly the situation has worsened for Google and all U.S. content companies. ${ }^{298}$ at A1.

291. James Temple, Google Says It Might Pull out of China, S.F. CHRON., Jan. 13, 2010,

292. Analyst: Android Phone Sales to Grow Tenfold, ReUTERs, May 11, 2009, http://http://www.pcmag.com/article2/0,2817,2346907,00.asp (last visited Mar. 5, 2010). at B3.

293. David Sarno, Google Phone Debut Put on Hold in China, L.A. TIMES, Jan. 20, 2010,

294. Temple, supra note 291, at A1.

295. See John Markoff \& Ashlee Vance, Hackers Who Leave No Trace, N.Y. TIMES, Jan 20,2010 , at B1.

296. Id.

297. Id. At the same time, China is developing its own operating software, name Kylin, which is resistant to cyber attacks that work on Linux, Unix and Windows based software; see Bill Gertz, China Develops Operating System For 'Cyber' War, WASH. TIMES, May 18, 2009 (Nat'l Weekly), at 17.

298. Esther Dyson, chairperson for EDventure Holdings has written a fascinating analysis:

Of course, censorship is not a big secret in China. China employs approximately 30,000 people as censors. They have names and faces, and they may negotiate with a publisher about a particularly sensitive topic. They are less likely to negotiate with bloggers, because there are so many bloggers, but the government reportedly does train bloggers in how to post in support of government policy, and if you are lucky you can get a job (reportedly at $\$ 0.50$ per post) doing the government's bidding.

So why has Google made a fuss and threatened to walk out of China? The answer probably stems from a combination of - or rather, a changing calculus aroundbusiness interests and values. The censorship issue has long grated at Google (Brin, with his Russian background, is reported to be especially hostile to censorship), but the company could argue that transparency about censorship was better than not serving China at all.

The censorship, however, has been getting worse. Perhaps the initial argument 
Google is engaged in a highly visible negotiation with the Chinese government. ${ }^{299}$ If it shuts down its search engine, Google will claim an expensive but moral victory, while China will in fact achieve greater content control over the Internet and greater market share for its national service. ${ }^{300}$ Ironically, shutting the Google search site then becomes a win-win solution that may allow Google to continue some other operations in China free from the moral dilemmas it now faces and confrontational position it now holds. ${ }^{301}$ It may also be a strategic retreat given the challenges Google has faced with Baidu over music search, cyber cafes, and staffing issues as well as ongoing government interference. ${ }^{302}$

The strategy followed by Google is one previously adopted by Yahoo! $!^{303}$ but not a viable one for Microsoft or Apple to follow. Yahoo! left China, selling back its majority stake in Alibaba (though it retains a thirtynine percent ownership interest). ${ }^{304}$ Microsoft and Apple, Google's real competitors, both have significant software and hardware sales that make their entanglement with China impossible to unwind. ${ }^{305}$ They face many of the same hurdles as Google but stand to lose a much greater investment were they to follow the moral high road being forged by Google. ${ }^{306} \mathrm{~A}$ temporary retreat on search services may open the door to renew cellular phone competition.

was wrong: Exposing Chinese censorship has done little to reduce it. Many Chinese support government censorship: They see it as a way to maintain civility and order. They know that their government is fragile, and they consider criticism harmful rather than cleansing. They trust their government to deal with problems over time....

Esther Dyson, The Google That Can Say No, DAILY News EGYPT, Jan. 20, 2010, available at $\mathrm{http}: / / \mathrm{www}$.thedailynewsegypt.com/uncategorized/the-google-that-can-say-no.html.

299. See Miguel Helft, Google Hopes To Retain Business Unit In China, N.Y. TIMES, Jan. 20,2010 , at B4

300. See id.

301. See generally id. (stating that most of Google's revenue comes from advertising that may not be affected).

302. See Andy Greenberg, The Guy Who's Beating Google, ForBES, Oct. 5, 2009, at 82 (discussing Robin Li the successful founder of Baidu).

303. See Sophie Taylor \& Anupretta Das, Microsoft-Yahoo War May Spur Alibaba Buyback, REUTERS, Apr. 7, 2008, http://www.reuters.com/article/idUSSHA11084320080407.

304. See id.

305. Microsoft, for example, was found to violate a license agreement over Chinese character fonts originally licensed for Windows 95 and ordered to halt sales of newer versions of the operating software. James Quinn, China Bans Microsoft From Selling Operating Systems, DAILY TELEGRAPH (LONDON), Nov. 18, 2009, at 4.

306. See Nancy Gohring, Ballmer: Microsoft Will Stay in China, PCWORLD, Jan. 14, 2010 ,

http://www.pcworld.com/businesscenter/article/186964/ballmer_microsoft_will_stay_in_china.ht $\mathrm{ml}$. 
Finally, the market may not be as clear cut as these assumptions suggest. Significant Chinese advertising funds are spent on the U.S. Google site, revenue which is unlikely to be lost as a result of the change. ${ }^{307}$ Moreover, an increasingly large number of people living in countries with Internet filtering are migrating to sophisticated software, virtual private networks, proxy servers or similar tools that connect through other countries' servers and thereby avoid the territorial limitations and the resulting censorship. ${ }^{308}$ For those users, Google will likely continue to be a preferred destination. Therefore, Google may risk less and have less to lose than its blog suggests. ${ }^{309}$ In contrast, Microsoft and Apple have fewer such silver linings to rationalize the coming thunder storm. If business is a race, then slowing one's opponent is almost as good as moving faster. Google remains the most nimble giant bestriding the Internet.

\section{PREDICTIONS \& CONCLUSION}

Beyond the legal challenges, Google remains in a very competitive fight with Microsoft for its ad revenue. ${ }^{310}$ The introduction of Bing may do more to impact the Internet giants than any of the pending litigation. But Google will not stand still. By next year, its search algorithm will have been updated, and its new operating system launched. ${ }^{311}$ In the upcoming environment, it is likely the corporate boards will be unlocked as the grappling intensifies. Google deserves to face antitrust scrutiny for its interlocking board memberships and the horizontal price fixing inherent in the Google Book Search. The discussions over orphan works will continue, hopefully with a more robust legislative solution, but orphan works will not

307. Tony D'Altorio, Google's Failure in China. . Revisited, DAILY MARKETS, Mar. 4 , 2010, http://www.dailymarkets.com/stocks/2010/03/04/google $\% \mathrm{E} 2 \% 80 \% 99$ s-failure-inchina\%E2\%80\%A6-revisited.

308. Dan Levin, Software Finds Profit In Bypassing Censors, INT'L HERALD TRIBUNE, Jan. 16, 2010, at 3 ("More than a million people in China, including human rights activists and expatriates, are using special software to circumvent the nation's complex online censorship system, known as the 'Great Firewall' . . . capitalizing on the growing desire of China's Internet users to fanqiang, or scale the wall ....").

309. Drummond, supra note 279.

310. See David Needle, Ballmer Happy With Bing's Progress, InTERnET News, Mar. 2, 2010 ,

http://www.internetnews.com/search/article.php/3868116/Ballmer+Happy+With+Bings+Progress .htm.

311. Posting of Sundar Pichai \& Linus Upson to the Official Google Blog, Introducing the Google Chrome OS, http://googleblog.blogspot.com/2009/07/introducing-google-chrome-os.html (July 7, 2009, 21:37 EST); Cade Metz, Google Research Head Dubs Holy PageRank'Over-

Hyped', THE REGISTER, Mar. 3, 2010, available at http://www.theregister.co.uk/2010/03/03/google_research_head_norvig_on_pagerank. 
derail the settlement. ${ }^{312}$ The benefits to Google of having immunity from suit by a group of parties that cannot be identified will not be the antitrust barrier to the Google Book Search. Despite legitimate antitrust concerns, the trajectory of the company remains that of a fierce competitor in a challenging market. Google's copyright liability for YouTube and the Google Book Search will continue to be matters of great speculation, but neither will have significant impacts on the company or copyright law. International issues will trouble Google, but these concerns are endemic to all U.S. software companies. ${ }^{313}$ They may preclude success in particular territories, but they will not threaten to undermine the company more broadly.

Only in the area of trademark law is Google vulnerable. The sale of advertising and promotion of keywords lies at the heart of Google's revenue stream. The sale of trademarks in its AdWords program will continually grow as a source of liability for the company in the U.S. and around the world. Google and other search companies will be compelled to stop trading in the trademarks of others. To the extent that the use of trademarks improve advertising sales rather than merely change where the advertising dollars are spent, the change could cost Google significant revenue.

Google has charted its course as an advertising company and it remains one. It will continue to explore new ways to deliver content that it can use to market its advertising, but it will not transform itself into a software company. The real question is whether, in an age of "free," more and more competitors are becoming advertising companies as well. Does Google deserve special treatment for its commitment not to be evil? If the standard is a comparison to its direct competitors, then it has failed. Google, along with Apple and Microsoft, provides valuable products and services, but in a tenacious, competitive manner. Google is no more - and no less-evil than the others.

312. Andrew Albanese, Debate Over Google Settlement Continues As Hearing Draws Near, PUBliSHERS WEEKLy, Feb. 12, 2010, http://www.publishersweekly.com/article/449124Debate_Over_Google_Settlement_Continues_as_Hearing_Draws_Near.php.

313. See Dan Levin, New Scrutiny on Censorship Issues for U.S. Companies in China, N.Y. TIMES, Mar. 1, 2010, available at http://www.nytimes.com/2010/03/02/technology/02internet.html?pagewanted=all (“Amazon and other U.S. companies doing business in China are coming under new scrutiny from politicians and human rights groups since Google's recent announcement that it planned to stop adhering to government demands that it censor search results in China and perhaps would pull out of the country .... So far Microsoft, Yahoo and Google have signed on to the voluntary code of conduct, but whether they will adhere to it remains uncertain.”). 